\title{
Experimental study of an Organic Rankine Cycle with HFO-1336mzz-Z as a low global warming potential working fluid for micro-scale low temperature applications
}

\author{
Joaquín Navarro-Esbría ${ }^{\mathrm{a}}$ Francisco Molés ${ }^{1, \mathrm{a}}$, Bernardo Peris ${ }^{\mathrm{a}}$, \\ Adrián Mota-Babiloni ${ }^{\mathrm{a}, \mathrm{b}}$, Konstantinos Kontomaris ${ }^{\mathrm{c}}$ \\ ${ }^{a}$ ISTENER Research Group. Department of Mechanical Engineering and Construction, \\ Campus de Riu Sec s/n, University Jaume I, E12071, Castellón (Spain). \\ ${ }^{\mathrm{b}}$ Departamento de Ingeniería Química y Nuclear, Universidad Politécnica de Valencia, \\ Camino de Vera 14, Valencia (Spain). \\ ${ }^{\mathrm{c}}$ Chemours Fluorochemicals, Wilmington, Delaware (USA).
}

\begin{abstract}
An experimental evaluation of HFO-1336mzz-Z as a low global warming potential working fluid for ORC systems in micro-scale low temperature applications has been conducted. The energy performance in a fully monitored ORC module has been analyzed varying the heat source temperatures between $140^{\circ} \mathrm{C}$ and $160^{\circ} \mathrm{C}$ and heat sink temperatures between $25^{\circ} \mathrm{C}$ and $40^{\circ} \mathrm{C}$. The $\mathrm{ORC}$ module uses a regenerative configuration allowing heat recovery not only from the heat source but also from the expanded vapor, thus improving the cycle thermal and electrical efficiency. The maximum gross electrical power generated was $1,100 \mathrm{~W}$, while the net electrical efficiency ranged from $5.5 \%$ to $8.3 \%$. The volumetric expander performance was analyzed by means of the filling factor, while deviations of expander operation from ideal performance were evaluated by means of the isentropic and overall expandergenerator efficiency. Net electrical efficiency, isentropic expander efficiency and volumetric expander performance obtained with HFO-1336mzz-Z in this work are higher than those obtained with HFC-245fa in a previous work using the same experimental facility.
\end{abstract}

Keywords: low GWP; HFO-1336mzz-Z; Organic Rankine Cycle; low temperature; micro-scale; experimental.

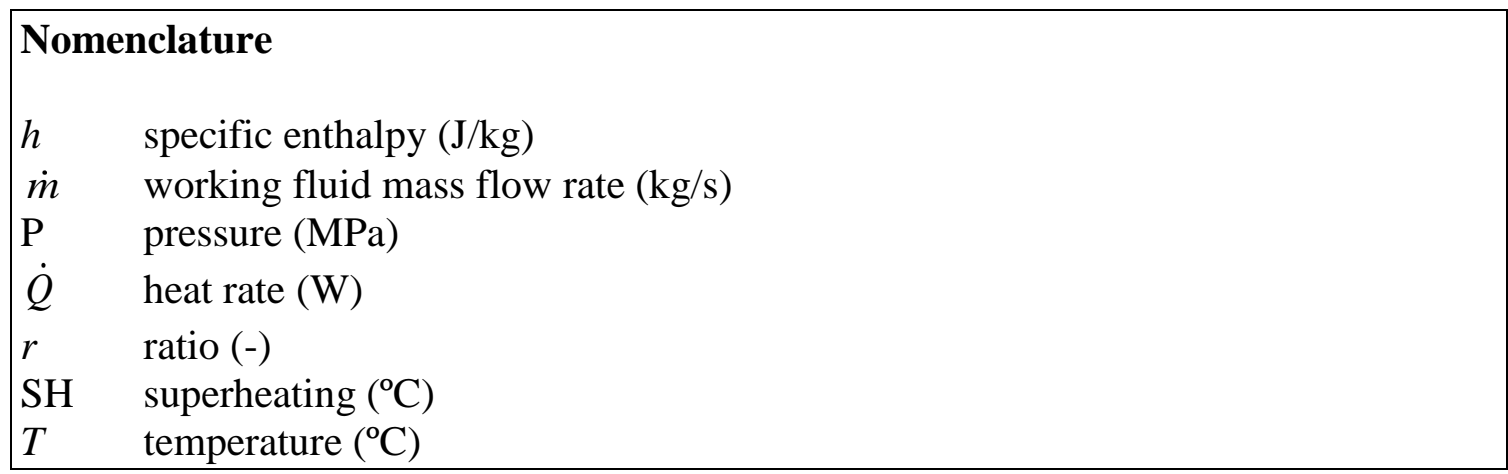

${ }^{1}$ Corresponding Author:

Tel: +34 964728134; fax: +34 964728106.

E-mail address: molesf@uji.es 


\begin{tabular}{|c|c|}
\hline$v$ & specific volume $\left(\mathrm{m}^{3} / \mathrm{kg}\right)$ \\
\hline$\dot{V}$ & volumetric flow rate $\left(\mathrm{m}^{3} / \mathrm{h}\right)$ \\
\hline$\dot{W}$ & electrical power (W) \\
\hline \multicolumn{2}{|c|}{ Greek symbols } \\
\hline$\varepsilon$ & effectiveness (-) \\
\hline$\eta$ & efficiency (-) \\
\hline$\rho$ & density $\left(\mathrm{kg} / \mathrm{m}^{3}\right)$ \\
\hline$\varphi$ & filling factor (-) \\
\hline \multicolumn{2}{|c|}{ Subscripts } \\
\hline c & cold \\
\hline cond & condensation \\
\hline $\mathrm{cr}$ & critical \\
\hline evap & evaporation \\
\hline $\exp$ & expander \\
\hline h & hot \\
\hline $\mathrm{i}$ & in \\
\hline in & internal \\
\hline is & isentropic \\
\hline 1 & liquid \\
\hline $\max$ & maximum \\
\hline $\mathrm{n}$ & net \\
\hline o & out \\
\hline oil & thermal oil \\
\hline ov & overall \\
\hline reg & regenerator \\
\hline $\mathrm{v}$ & volume \\
\hline $\mathrm{pp}$ & pump \\
\hline $\mathrm{W}$ & cooling water \\
\hline wf & working fluid \\
\hline \multicolumn{2}{|c|}{ Acronyms } \\
\hline $\mathrm{CHP}$ & Combined Heat and Power \\
\hline GWP & Global Warming Potential \\
\hline $\mathrm{HCFO}$ & HydroChloroFluoroOlefin \\
\hline $\mathrm{HFC}$ & HydroFluoroCarbon \\
\hline HFO & HydroFluoroOlefin \\
\hline ODP & Ozone Depletion Potential \\
\hline ORC & Organic Rankine Cycle \\
\hline
\end{tabular}

\section{Introduction}

Due to environmental constraints, the Organic Rankine Cycle (ORC) has been attracting increasing attention over the past decades [1]. Unlike the conventional steam Rankine cycle, an ORC uses an organic working fluid to enable cost-effective use of low 
temperature heat sources for both power and Combined Heat and Power (CHP) applications [2]. It also enables cost-effective micro-scale applications [3], i.e. applications generating less than $15 \mathrm{kWe}$ of electrical power [4]. Besides other advantages $[5,6]$, the ORC technology is considered mature relative to other techniques for the direct conversion of heat to power [7]. Several ORC systems have been installed for recovering waste heat from industrial processes (e.g. in the cement [8], ceramic [9] or oil industry [10]) or from power systems (e.g. internal combustion engines [11]). ORC systems have also been used for converting renewable solar [12], biomass [13] and geothermal [14] energy into power.

This wide range of potential applications has motivated research to provide suitable ORC solutions. Expander technology, working fluid choice and thermodynamic cycle configuration have a major influence on ORC system performance and economics. Volumetric or positive displacement expanders have been extensively investigated for micro-scale, low temperature ORC applications [15]. They are more effective for smallscale units, characterized by lower flow rates, higher pressure ratios, and significantly lower rotational speeds than turbomachines. Moreover, they tolerate some liquid content, e.g. drops carried from the evaporator or forming through condensation during expansion [16]. Working fluid selection has been also widely investigated; it has been found to be highly dependent on the target application [17] and it must balance various trade-offs, as no universally optimal fluid has been identified. Quoilin et al. [16] have found that HFC-245fa is a common working fluid in commercial ORC installations, mainly used in waste heat recovery from low temperature heat sources. They further observed that, at the present time, most commercial ORC plants follow a simple architecture: sub-critical working conditions, single-component working fluids, single evaporation pressure, and possible use of a recuperator heat exchanger.

Attending to environmental issues, HFC-245fa has a GWP of 858 [18]. Low-GWP working fluids have been recently proposed as potential replacements for HFC-245fa in various applications, including ORC systems [19]. HFO-1336mzz-Z (cis$\mathrm{CF}_{3} \mathrm{CH}=\mathrm{CHCF}_{3}$; 1,1,1,4,4,4-hexafluoro-2-butene; CAS No. 692-49-9; previously referred to as DR-2) is a hydrofluoroolefin (HFO) with a GWP of 2 [18] and zero ODP [20,21]. Molés et al. [22] computed attractive performance of ORC systems using HFO$1336 \mathrm{mzz}-\mathrm{Z}$ as the working fluid for low temperature heat recovery. They also found that system efficiency was benefitted substantially by the use of a recuperator. Table 1 shows the main thermophysical properties of HFC-245fa and HFO-1336mzz-Z. HFO$1336 \mathrm{mzz}-Z$ has recently received a safety classification of A1 (lower toxicity, no flammability) according to ASHRAE Standard 34, with an Occupational Exposure Limit (OEL) of $500 \mathrm{ppm}$. Fig. 1 shows the temperature-entropy diagrams and vapor pressure curves for both fluids. HFO-1336mzz-Z generates substantially lower pressures than HFC-245fa, especially at high temperatures. It would, therefore, allow higher evaporating temperatures than HFC-245fa, when the maximum permissible evaporating temperature is limited by the maximum permissible pressure of the available equipment. Extensive HFO-1336mzz-Z pressure-temperature-density measurements have recently been reported by Tanaka et al. [23]. They were used to develop an equation of state explicit in the Helmholtz free energy for HFO-1336mzz-Z by Akasaka and Lemmon [24]. 
Table 1. Thermophysical properties of HFC-245fa and HFO-1336mzz-Z.

Fig. 1. T-s diagram and vapor pressure curves for HFC-245fa and HFO-1336mzz-Z.

To the authors' knowledge, there is a lack of experimental data for ORC systems using non-flammable, low GWP working fluids. Datla and Brasz [25] compared the performance of HCFO-1233zd-E and HFC-245fa in a $75 \mathrm{~kW}$ standard ORC system with a radial inflow turbine at a single operating point. They demonstrated $8.7 \%$ higher net system efficiency with HCFO-1233zd-E. Molés et al. [26] conducted an experimental evaluation of HCFO-1233zd-E as an HFC-245fa replacement in ORC systems for low temperature heat sources. They obtained lower heat rate and electrical power with HCFO-1233zd-E due to its lower vapor density. Eyerer et al. [27] demonstrated a $6.92 \%$ higher ORC system efficiency with HCFO-1233zd-E relative to HFC-245fa. Finally, Kontomaris et al. [28] evaluated HFO-1336mzz-Z in a prototype ORC system based on a reciprocating expander with a capacity of about $12 \mathrm{kWe}$. They measured HFO-1336mzz-Z performance at a single expander inlet temperature of $196^{\circ} \mathrm{C}$ and at condensing temperatures of $60^{\circ} \mathrm{C}$ and $80^{\circ} \mathrm{C}$.

This work reports an experimental study of an ORC system with HFO-1336mzz-Z as a low GWP working fluid for micro-scale, low temperature applications. It covers a wide range of operating conditions (e.g. heat source and heat sink temperatures) not previously reported. The rest of the paper is organized as follows: Section 2 describes the experimental setup and methodology; Section 3 reports and discusses the main results; finally, Section 4 summarizes the main conclusions.

\section{Experimental setup and methodology}

\subsection{ORC system}

A monitored commercial ORC module [26] was used as a test bench for the experiments carried out in this work. It uses a regenerative configuration, shown in Fig. 2 , that allows not only recovering the thermal energy from the heat source but also the waste heat from the expander outlet, thus improving the system electrical efficiency. Other features of the commercial ORC module are listed in Table 2.

Fig. 2. Schematic representation of a regenerative ORC.

Table 2. Commercial ORC module features.

\subsection{Heating and cooling loops}

The test bench is completed with two secondary circuits, a heat sink cooling water loop and a heat source thermal oil loop. The heat sink cooling water loop consists of a closed-type cooling system, which allows controlling the cooling water temperature. 
The heat source thermal oil loop includes an electric boiler, which allows controlling the thermal oil temperature.

\subsection{Measurements and calculations}

The temperature and pressure at the inlet and outlet of each basic equipment component of the test facility are measured using K-type thermocouples and piezoelectric pressure gauges, respectively. The thermodynamic states of the working fluid are calculated using REFPROP[29] and HFO-1336mzz-Z property file provided by Chemours. The working fluid mass flow rate is measured by means of a Coriolis effect mass flowmeter, the heat sink cooling water loop volumetric flow rate is measured with an electromagnetic flowmeter and the heat source thermal oil loop volumetric flow rate is measured with a Vortex flowmeter. The electrical power generated by the expander and the electrical power consumed by the pump are obtained with two digital wattmeters. All measurements are gathered with a data acquisition system and monitored through a personal computer. A summary of the measured parameters and the sensors used in this work is presented in Table 3, indicating the uncertainty associated with each measurement.

Table 3. Measured parameters, measuring instruments and measurement uncertainty.

For the analysis of the experimental data obtained during steady-state tests, various equations have been used. Input heat rate is defined as the rate of heat transfer to the working fluid at the evaporator and it is obtained as the product of the working fluid mass flow rate and the enthalpy difference between the evaporator inlet and outlet, as shown in Eq. 1. Similarly, output heat rate is defined as the rate of heat rejected by the working fluid at the condenser and it is obtained through Eq. 2.

$$
\begin{aligned}
& \dot{Q}_{w f, \text { evap }}=\dot{m}\left(h_{\text {evap }, o}-h_{\text {evap }, i}\right) \\
& \dot{Q}_{w f, \text { cond }}=\dot{m}\left(h_{\text {cond }, i}-h_{\text {cond }, o}\right)
\end{aligned}
$$

The rate of heat recovered at the regenerator is calculated through Eq. 3. The regenerator effectiveness is obtained through Eq. 4, where maximum heat rate is the heat rate leading to a pinch point equal to zero.

$$
\begin{gathered}
\dot{Q}_{w f, r e g}=\dot{m}\left(h_{\text {reg }, l, o}-h_{r e g, l, i}\right) \\
\varepsilon_{r e g}=\frac{\dot{Q}_{w f, r e g}}{\dot{Q}_{w f, r e g, \max }}
\end{gathered}
$$

The net electrical power output is calculated from the measured electrical power generated by the expander and the measured electrical power consumed by the pump using Eq. 5. The net electrical efficiency of the system is obtained through Eq. 6. 


$$
\begin{gathered}
\dot{W}_{n}=\dot{W}_{e x p}-\dot{W}_{p p} \\
\eta_{n}=\frac{\dot{W}_{n}}{\dot{Q}_{w f, e v a p}}
\end{gathered}
$$

Expander performance is quantified in terms of various ratios. The expander isentropic efficiency is obtained through Eq. 7, as the ratio of the enthalpy difference in the real expansion process to the isentropic enthalpy difference. The ratio of the measured electrical power generated by the expander to the maximum electrical power that could be ideally obtained in an isentropic expansion process is defined as the overall expander-generator efficiency through Eq. 8. The volumetric performance of the expander is represented by Eq. 9, as the ratio of the calculated volumetric flow rate at the expander inlet to the theoretical volumetric flow rate displaced by the expander, named the filling factor [30]. Another parameter used for expander performance analysis is the specific volume ratio in the expander, calculated through Eq. 10.

$$
\begin{gathered}
\eta_{i s}=\frac{h_{\text {exp }, i}-h_{\text {exp }, o}}{h_{\text {exp }, i}-h_{\text {exp }, o, i s}} \\
\eta_{o v}=\frac{\dot{W}_{\text {exp }}}{\dot{m}\left(h_{\text {exp }, i}-h_{\text {exp },, i s}\right)} \\
\varphi=\frac{\dot{m} v_{\text {exp }, i} 3600}{\dot{V}_{\text {exp }, i, i n}} \\
r_{v}=\frac{v_{\text {exp }, o}}{v_{\text {exp }, i}}
\end{gathered}
$$

The uncertainties propagated to calculated parameters from uncertainties in measured parameters are estimated using the RSS method [31] and shown in Table 4.

Table 4. Uncertainties for calculated parameters.

\subsection{Methodology of experiments}

HFO-1336mzz-Z performance in the commercial ORC module was tested over an operating range expected using low grade temperature heat sources. The degree of vapor superheat at the expander inlet was maintained approximately constant, at values near $10^{\circ} \mathrm{C}$. The cooling water and thermal oil volumetric flow rates were kept approximately constant, at values shown in Table 5. The cooling water inlet temperature was set at three values, nominally 25,32 and $40{ }^{\circ} \mathrm{C}$. The thermal oil inlet temperature was varied from about $140^{\circ} \mathrm{C}$ to more than $155^{\circ} \mathrm{C}$. The experimental data consist of 100 steady-state tests, which are represented in Fig. 3. 
Fig. 3. Thermal oil and cooling water inlet temperatures specified during steady-state tests.

Table 5. Range of operating conditions in the experimental steady-state tests.

The system state is considered steady when fluctuations of all measured parameters, sampled every $1 \mathrm{~s}$, remain below $1 \%$ for at least $15 \mathrm{~min}$ (900 measurements of each parameter). Each test is obtained, once the steady state is reached, averaging over 10 minutes all the measured parameters.

\subsection{Data validation}

In order to check the accuracy of the measurements, data validation is conducted comparing the input and output heat rates measured from the working fluid side and the secondary fluids side. In this way, the rate of heat transferred to the working fluid at the evaporator is compared to the rate of heat transferred from the thermal oil. Similarly, the heat rate rejected by the working fluid at the condenser is compared to the heat rate removed by the cooling water. Both energy balances are presented in Fig. 4.

Fig. 4. Data validation comparing working fluid and secondary fluids heat transfer rates at the evaporator and condenser.

The heat rate supplied by the thermal oil at the evaporator is obtained through Eq. 11 using the thermal oil volumetric flow rate and its evaporator inlet and outlet temperatures. Similarly, the rate of heat removed by the cooling water at the condenser is obtained through Eq. 12.

$$
\begin{gathered}
\dot{Q}_{\text {oil }, \text { evap }}=\dot{V}_{\text {oil }} \rho c_{p}\left(T_{\text {oil }, i}-T_{\text {oil }, o}\right) \\
\dot{Q}_{w, \text { cond }}=\dot{V}_{w} \rho c_{p}\left(T_{w, o}-T_{w, i}\right)
\end{gathered}
$$

\section{Results and discussion}

This section presents the results of the analysis conducted from the experimental data obtained during the tests. This analysis has been focused on the overall behavior of the ORC module and expander performance, and finally, comparing the performance obtained with HFO-1336mzzZ with that obtained with HFC-245fa in the same ORC module.

The mass flow rate of the ORC working fluid is shown in Fig. 5a. It increases with the thermal oil inlet temperature, while it is not significantly affected by the cooling water inlet temperature. The mass flow rate of the working fluid is related to its density at the expander inlet, due to the constant superheating at the volumetric expander inlet. The vapor density at the expander inlet is presented in Fig. 5b. Evaporating and condensing temperatures are shown in Fig. 5c and Fig. 5d, respectively. As expected, evaporating 
temperatures are increasing with the thermal oil inlet temperatures, while condensing temperatures depend on the cooling water inlet temperatures.

Fig. 5. (a) Mass flow rate, (b) density at expander inlet, (c) evaporating temperature and (d) condensing temperature.

Input heat rate, presented in Fig. 6a, ranges from $7,000 \mathrm{~W}$ to $11,000 \mathrm{~W}$. It increases with the thermal oil inlet temperature and slightly decreases with the cooling water inlet temperature. Input heat rate is related to the mass flow rate of the working fluid and the evaporating and condensing temperatures. Output heat rate, shown in Fig. 6b, ranges from about $6,500 \mathrm{~W}$ to about $9,500 \mathrm{~W}$. It shows trends with heat source and sink temperatures similar to those observed for the input heat rate. As mentioned before, the ORC uses a regenerative configuration that allows recovering heat not only from the heat source but also the expanded vapor. The rate of heat recovery from the vapor exiting the expander by the regenerator is presented in Fig. 6c; it ranges from 2,100 W to $3,500 \mathrm{~W}$ and follows trends similar to those observed for the input and output heat rates. The regenerator effectiveness is about $74 \%$, as it can be seen in Fig. 6d. Moreover, as it is used a dry working fluid, condensation is occurring only in the condenser.

Fig. 6. (a) Input heat rate, (b) output heat rate, (c) rate of heat recovered by regenerator and (d) regenerator effectiveness.

Fig. 7a shows the electrical power generated by the expander-generator. The maximum electrical power generated is $1,100 \mathrm{~W}$. As expected, electrical power generated increases for higher thermal oil inlet temperatures and lower cooling water inlet temperatures, due to the higher mass flow rate of the working fluid and the greater difference between evaporating and condensing temperatures. The electrical power consumed by the pump, presented in Fig. $7 \mathrm{~b}$, ranges from $145 \mathrm{~W}$ to $210 \mathrm{~W}$; it increases with thermal oil inlet temperature and it is mainly related to the mass flow rate and working fluid pressure ratio. The net electrical power output of the ORC module, shown in Fig. 7c, reaches a maximum value of $900 \mathrm{~W}$. The net electrical power output of the ORC module depends on the electrical power generated by the expander-generator and the electrical power consumed by the pump; it increases with the thermal oil inlet temperature and decreases with the cooling water inlet temperature. The net electrical efficiency, shown in Fig. 7d, ranges from 5.5\% to 8.3\%. As expected, it increases with the thermal oil inlet temperature and decreases with the cooling water inlet temperature.

Fig. 7. (a) Electrical power generated by the expander, (b) electrical power consumed by the pump, (c) net electrical power output and (d) net electrical efficiency.

Various expander performance indicators are shown in Fig. 8. The volume ratio through the expander, presented in Fig. 8a, ranges between 6.5 and 10.5. The volume ratio is mainly influenced by the evaporating and condensing temperatures, and therefore it 
increases with the thermal oil inlet temperature and decreases with the cooling water inlet temperature. The filling factor, shown in Fig. 8b, quantifies expander volumetric performance; it takes values around 1.25. The isentropic efficiency is presented in Fig. $8 \mathrm{c}$. It shows a maximum value of $87 \%$ and it decreases with the thermal oil inlet temperature due to the increase in the volume ratio through the expander and the related under-expansion energy losses. The overall expander-generator efficiency, shown in Fig. 8d, ranges from $48.5 \%$ to $57.5 \%$. It shows different trends with thermal oil and cooling water temperatures from the isentropic efficiency because it is affected by the part-load alternator electrical efficiency and its maximum electrical efficiency, among other energy losses.

Fig. 8. (a) Volume ratio, (b) filling factor, (c) isentropic efficiency and (d) overall expander-generator efficiency.

Regarding the expander performance, a comparison has been made between the results obtained in this work and the results obtained in previous works. In a previous experimental analysis [26], an experimental evaluation of the working fluids HFC-245fa and HCFO-1233zd-E in ORC systems for low temperature heat sources has been conducted, using the same experimental facility and similar operating conditions as in this work. The filling factor for HFC-245fa and HCFO-1233zd-E presents values around 1.375, as shown in Fig. 9a. Comparing the filling factor of the expander for the different working fluids, the values obtained with HFO-1336mzz-Z in this work are lower than those obtained with HFC-245fa and HCFO-1233zd-E. The isentropic efficiency for HFC-245fa and for HCFO-1233zd-E has a maximum value of $70 \%$ and $75 \%$, respectively, as shown in Fig. 9b. Those values are lower than those obtained with HFO-1336mzz-Z in this work. The overall expander-generator efficiency of the expander has similar values for all the working fluids, as shown in Fig. 9c.

Fig. 9. Comparison for different working fluids of: (a) filling factor, (b) isentropic efficiency and (c) overall expander-generator efficiency.

Regarding the system behavior, in a previous theoretical analysis [22] an evaluation of the low GWP fluid HFO-1336mzz-Z as an alternative to HFC-245fa in ORC systems for low temperature heat sources was carried out. The results obtained indicate that the ORC systems working with HFO-1336mzz-Z can achieve higher values of net electrical efficiency than those working with HFC-245fa, with this increase accentuated for high condensing temperatures. The experimental results for HFC-245fa obtained in the previous experimental analysis [26] show a net electrical efficiency ranging from 5\% to $9.7 \%$. Net electrical efficiency at the highest cooling water inlet temperature obtained in this work with HFO-1336mzz-Z is higher than the net electrical efficiency obtained with HFC-245fa, as expected from the previous theoretical analysis.

\section{Conclusions}

In this paper, a regenerative ORC experimental system with a volumetric expander and HFO-1336mzz-Z as a low GWP working fluid has been tested for micro-scale, low temperature applications. This work contributes to mitigate the lack of experimental data for ORC systems using non-flammable low GWP working fluids, presenting an 
experimental analysis of the behavior of one of this type of working fluids, HFO$1336 \mathrm{mzz}-Z$, and comparing it with that observed for other working fluids in the same experimental facility in previous works.

An experimental campaign has been conducted, with the inlet heat source temperature varied from about $140^{\circ} \mathrm{C}$ to more than $155^{\circ} \mathrm{C}$ and performance data collected from 100 steady-state tests. The ORC module uses a regenerative configuration with regenerator effectiveness values obtained around 74\%. System parameters such as heat rates, electrical powers, and expander performance indicators have been investigated.

Based on the experimental analysis the following conclusions can be drawn:

- Maintaining a constant value of $10^{\circ} \mathrm{C}$ at the expander inlet superheating degree, it has been observed that the working fluid mass flow rate and evaporating temperature increase with the thermal oil inlet temperature. The input heat rate, related to the mass flow rate and evaporating and condensing temperatures, increase with the thermal oil inlet temperature and slightly decrease with the cooling water inlet temperature.

- Expander performance has been characterized by means of various indicators. The volumetric performance of the expander is analyzed by means of the filling factor, with values around 1.25. The isentropic expander efficiency has a maximum value of $87 \%$, while the overall expander-generator efficiency of the expander ranges from $48.5 \%$ to $57.5 \%$. The overall expander-generator efficiency shows different trends from the isentropic efficiency, as it is affected by the alternator electrical efficiency operating at partial loads, among other energy losses.

- A comparison has been made between the results obtained in this work and the results obtained in previous works using HFC-245fa and HCFO-1233zd-E. Regarding the expander performance, the isentropic efficiency obtained with HFO-1336mzz-Z in this work is higher than those obtained with HFC-245fa and HCFO-1233zd-E, while the filling factor values obtained with HFO-1336mzz-Z in this work are lower than those obtained with HFC-245fa and HCFO-1233zdE. Similar values of the overall expander-generator efficiency are obtained for all the working fluids.

- Regarding the system behavior, the net electrical efficiency obtained in this work ranges from $5.5 \%$ to $8.3 \%$. For the highest cooling water inlet temperatures, net electrical efficiency obtained with HFO-1336mzz-Z in this work is higher than the net electrical efficiency obtained with HFC-245fa in a previous work using the same experimental facility, as expected from the previous theoretical analysis.

\section{Acknowledgements}

The authors thankfully acknowledge the Chemours Company for supporting this work. The authors acknowledge the Spanish Government for the financial support under projects ENE2015-70610-R and RTC-2015-4193-3. Furthermore, the authors 
acknowledge the University Jaume I of Spain for the financial support under the Ph.D. grant PREDOC/2013/28, project P1-1B2015-38.

\section{References}

[1] B. Fu, S. Hsu, C. Liu, Y. Liu, Statistical analysis of patent data relating to the organic Rankine cycle, Renewable and Sustainable Energy Reviews 29 (2014), 986 994.

[2] B. Peris, J. Navarro-Esbrí, F. Molés, M. González, A. Mota-Babiloni, Experimental characterization of an ORC (organic Rankine cycle) for power and CHP (combined heat and power) applications from low grade heat sources, Energy 82 (2015), 269 - 276.

[3] B. Peris, J. Navarro-Esbrí, F. Molés, J. Martí, A. Mota-Babiloni, Experimental characterization of an Organic Rankine Cycle (ORC) for micro-scale CHP applications, Applied Thermal Engineering 79 (2015), $1-8$.

[4] M. Dentice, M. Saso, S. Sibilio, L. Vanoli, Micro-combined heat and power in residential and light commercial applications, Applied Thermal Engineering 23 (2003), $1247-1259$.

[5] P. Bombarda, C.M. Invernizzi, C. Pietra, Heat recovery from diesel engines: a thermodynamic comparison between Kalina and ORC cycles, Applied Thermal Engineering 30 (2010), $212-219$.

[6] H. Chen, D.Y. Goswami, E.K. Stefanakos, A review of thermodynamic cycles and working fluids for the conversion of low-grade heat, Renewable and Sustainable Energy Reviews 14 (2010), 3059 - 3067.

[7] B.F. Tchanche, G. Lambrinos, A. Frangoudakis, G. Papadakis, Low grade heat conversion into power using organic Rankine cycles - a review of various applications, Renewable and Sustainable Energy Reviews 15 (2011), 3963 - 3979.

[8] J. Wang, Y. Dai, L. Gao, Exergy analyses and parametric optimizations for different cogeneration power plants in cement industry, Applied Energy 86 (2006), 941 - 948.

[9] B. Peris, J. Navarro-Esbrí, F. Molés, A. Mota-Babiloni, Experimental study of an ORC (organic Rankine cycle) for low grade waste heat recovery in a ceramic industry, Energy 85 (2015), $534-542$.

[10] J.S. Meacher, Organic Rankine Cycle systems for waste heat recovery in refineries and chemical process plants, in: ESL-IE-81-04-90, Proceedings from the $3^{\text {rd }}$ Industrial Energy Technology Conference, Houston, TX, 1981.

[11] B. Peris, J. Navarro-Esbrí, F. Molés, Bottoming organic Rankine cycle configurations to increase Internal Combustion Engines power output from cooling water waste heat recovery, Applied Thermal Engineering 61 (2013), 364 - 371. 
[12] M. Wang, J. Wang, Y. Zhao, P. Zhao, Y. Dai, Thermodynamic analysis and optimization of a solar-driven regenerative organic Rankine cycle (ORC) based on flatplate solar collectors, Applied Thermal Engineering 50 (2013), 816 - 825.

[13] Y. Huang, D.R. McIlveen-Wright, S. Rezvani, M.J. Huang, Y.D. Wang, A.P. Roskilly, N.J. Hewitt, Comparative techno-economic analysis of biomass fuelled combined heat and power for commercial buildings, Applied Energy 112 (2013), 518 525 .

[14] X. Liu, X. Wang, C. Zhang, Sensitivity analysis of system parameters on the performance of the organic Rankine cycle system for binary-cycle geothermal power plants, Applied Thermal Engineering 71 (2014), 175 - 183.

[15] B. Peris, J. Navarro-Esbrí, F. Molés, R. Collado, A. Mota-Babiloni, Performance evaluation of an Organic Rankine Cycle (ORC) for power applications from low grade heat sources, Applied Thermal Engineering 75 (2014), 763 - 769.

[16] S. Quoilin, M. Van Den Broek, S. Declaye, P. Dewallef, V. Lemort, Technoeconomic survey of Organic Rankine Cycle (ORC) systems, Renewable and Sustainable Energy Reviews 22 (2013), 168 - 186.

[17] A. Desideri, S. Gusev, M. Van Den Broek, V. Lemort, S. Quoilin, Experimental comparison of organic fluids for low temperature ORC (organic Rankine cycle) systems for waste heat recovery applications, Energy 97 (2016), 460 - 469.

[18] G. Myhre, D. Shindell, F.M. Breon, W. Collins, J. Fuglestvedt, J. Huang, D. Koch, J.F. Lamarque, D. Lee, B. Mendoza, T. Nakajima, A. Robock, G. Stephens, T. Takemura, H. Zhang, Anthropogenic and Natural Radiative Forcing, in: Climate Change: the Physical Science Basis. Contribution of Working Group I to the Fifth Assessment Report of the Intergovernmental Panel on Climate Change, T.F. Stocker, D. Qin, G.K. Plattner, M. Tignor, S.K. Allen, J. Boschung, A. Nauels, Y. Xia, V. Bex, P.M. Midgley (Eds.), , Cambridge University Press, Cambridge, United Kingdom and New York, NY, USA, 2013.

[19] F. Molés, Theoretical and experimental analysis of low GWP working fluids as alternatives to HFC-245fa in low temperature organic Rankine cycles, Ph.D. Thesis, University Jaume I, Castellón, Spain, 2015.

[20] K. Kontomaris, B. Minor, B. Hydutsky, Low GWP working fluid for organic Rankine Cycles: DR-2; chemical stability at high temperatures, in: 2nd International Seminar on ORC Power Systems, ASME ORC 2013, Rotterdam, The Netherlands, Oct. 7-8, 2013.

[21] K. Kontomaris, HFO-1336mzz-Z: high temperature chemical stability and use as a working fluid in Organic Rankine Cycles, in: 15th International Refrigeration and Air Conditioning Conference at Purdue, West Lafayette, Indiana, USA, July 14-17, 2014.

[22] F. Molés, J. Navarro-Esbrí, B. Peris, A. Mota-Babiloni, A. Barragán-Cervera, K. Kontomaris, Low GWP alternatives to HFC-245fa in Organic Rankine Cycles for low 
temperature heat recovery: HCFO-1233zd-E and HFO-1336mzz-Z, Applied Thermal Engineering 71 (2014), $204-212$.

[23] Tanaka, K., Akasaka, R., Sakaue, E., Ishikawa, J. \& Kontomaris, K., Thermodynamic properties of cis-1,1,1,4,4,4-hexafluoro-2-butene (HFO$1336 \mathrm{mzz}(\mathrm{Z})$ ): Measurements of the $\mathrm{p} \rho \mathrm{T}$ property and determinations of vapor pressures, saturated liquid and vapor densities, and critical parameters. J. Chem. Eng. Data, 2016, 61 (7), 2467-2473.

[24] Akasaka, R. \& Lemmon, Eric W. (2016). A Helmholtz energy equation of state for cis-1,1,1,4,4,4-hexafluoro-2-butene (R-1336mzz(Z)). Proceedings of the 8th Asian Conference on Refrigeration and Air Conditioning ACRA2016-00088, Taipei, Taiwan, May 15-17.

[25] B.V. Datla, J.J. Brasz, Comparing R1233zd and R245fa for low temperature ORC application, in: $15^{\text {th }}$ International Compressor Engineering Conference at Purdue, 14-17 July, 2014.

[26] F. Molés, J. Navarro-Esbrí, B. Peris, A. Mota-Babiloni, Experimental evaluation of HCFO-1233zd-E as HFC-245fa replacement in an Organic Rankine Cycle system for low temperature heat sources, Applied Thermal Engineering 98 (2016), 954 - 961.

[27] S. Eyerer, C. Wieland, A. Vandersickel, H. Splethoff, Experimental study of an ORC (Organic Rankine Cycle) and analysis of R1233zd-E as a drop-in replacement for R245fa for low temperature heat utilization, Energy 103 (2016), 660 - 671.

[28] K. Kontomaris, L. D. Simoni, M. Nilsson, T. Hamacher and H. Nes Rislå, Combined heat and power from low temperature heat: $\mathrm{HFO}-1336 \mathrm{mzz}(\mathrm{Z})$ as a working fluid for Organic Rankine Cycles, in: Proceedings of the 16th International Refrigeration and Air Conditioning Conference at Purdue, July 11-14, 2016.

[29] E.W. Lemmon, M.L. Huber, M.O. McLinden, REFPROP, NIST Standard Reference Database 23, v.8, National Institute of Standards, Gaithersburg, MD, USA, 2007.

[30] R. Zanelli, D. Favrat, Experimental investigation of a hermetic scroll expander generator, in: Proceedings of the International Compressor Engineering Conference at Purdue, 1994, 459 - 464.

[31] J.R. Taylor, An introduction to error analysis, The study of uncertainties in physical measurements, University Science Books, Sausalito, USA, 1997. 

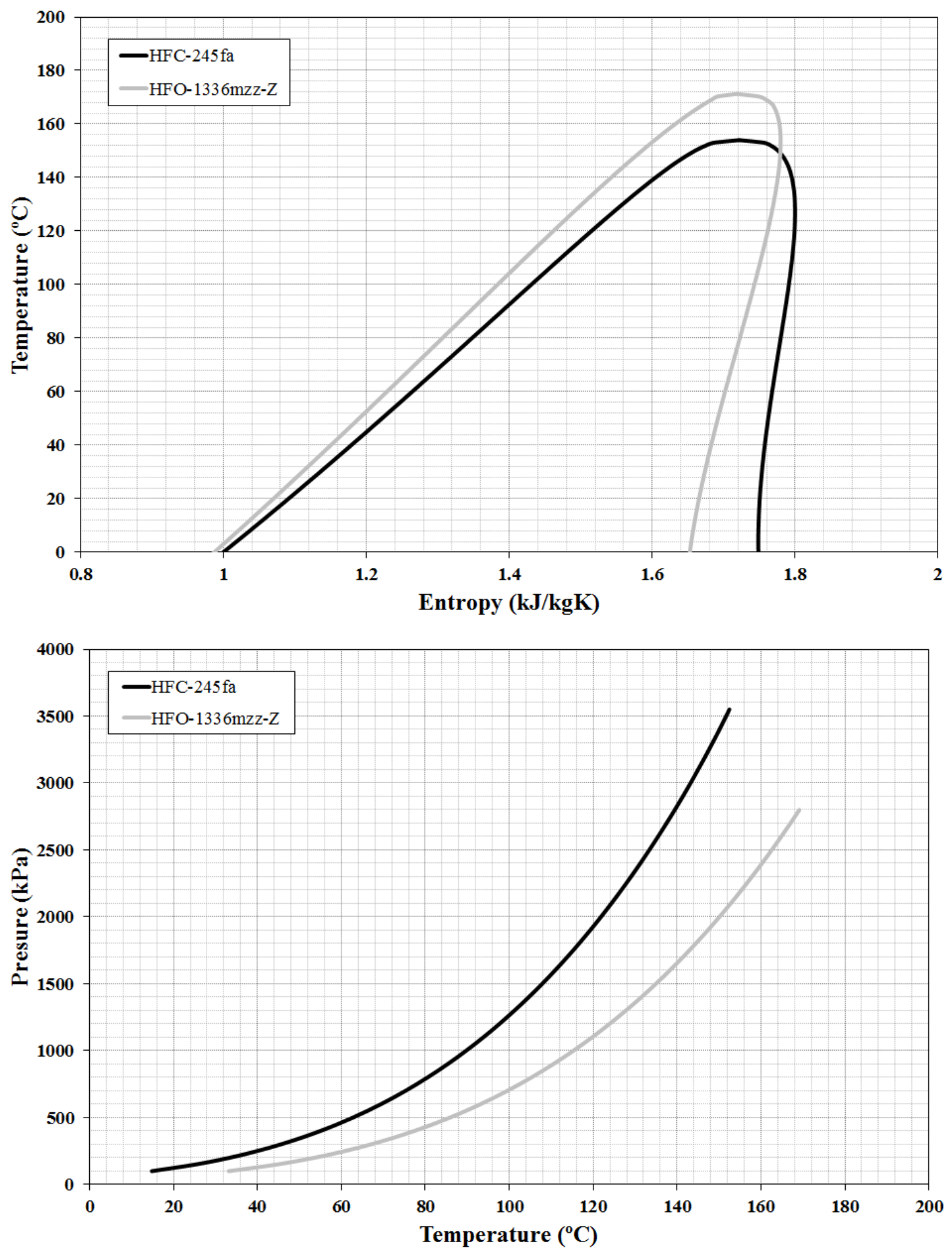

Fig. 1. T-s diagram and vapor pressure curves for HFC-245fa and HFO-1336mzz-Z. 


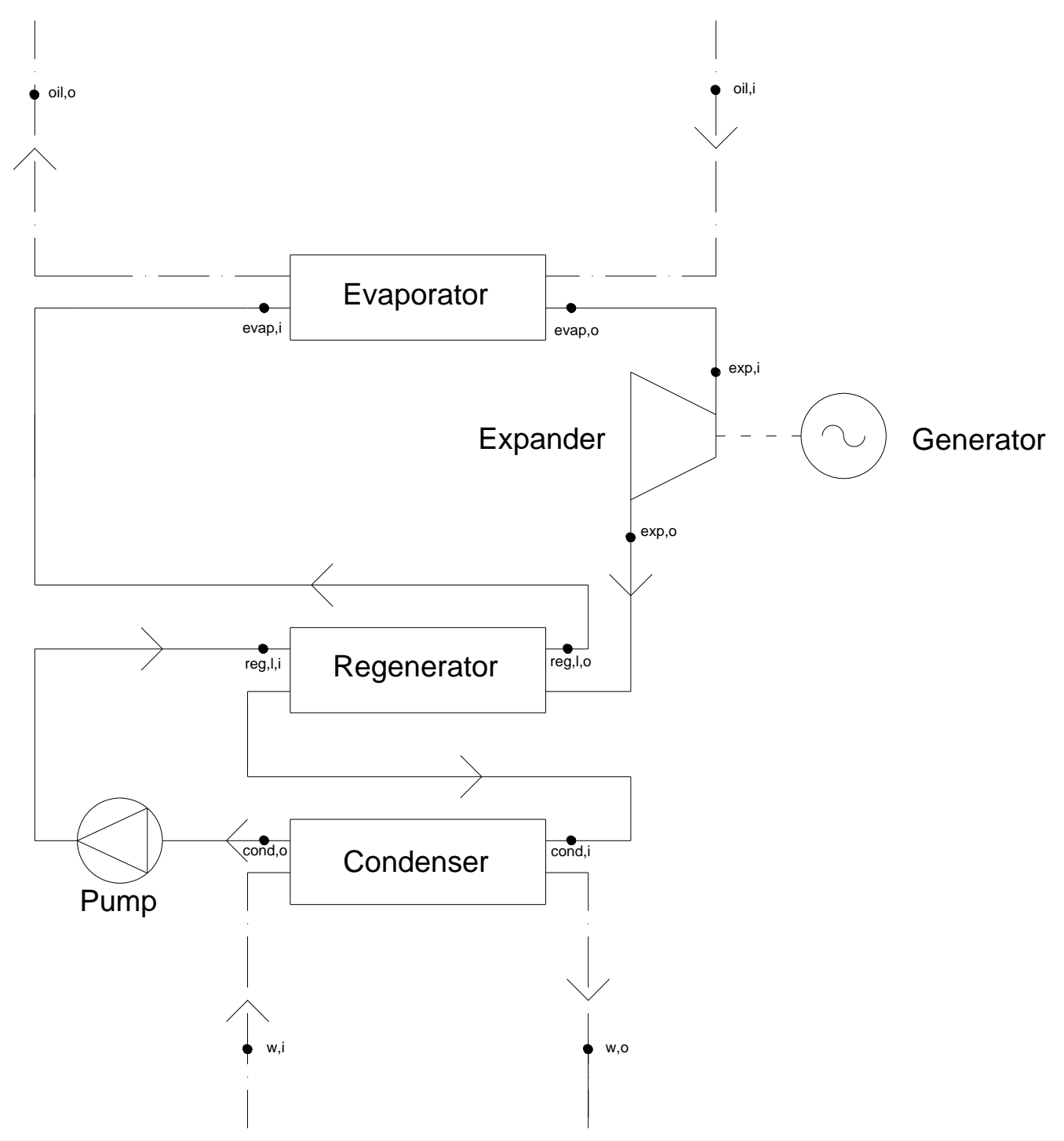

Fig. 2. Schematic representation of a regenerative ORC. 


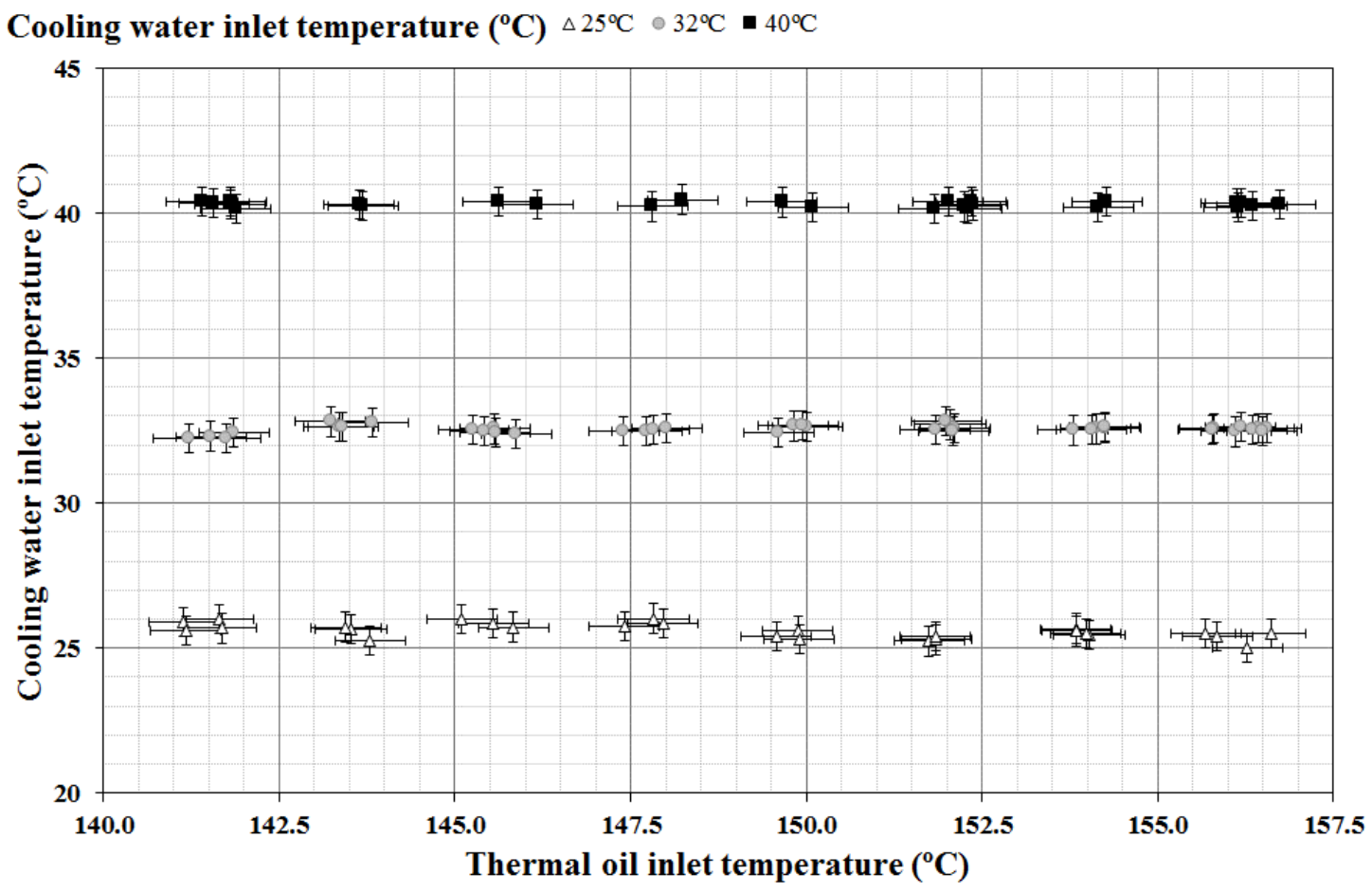

Fig. 3. Thermal oil and cooling water inlet temperatures specified during steady-state tests. 

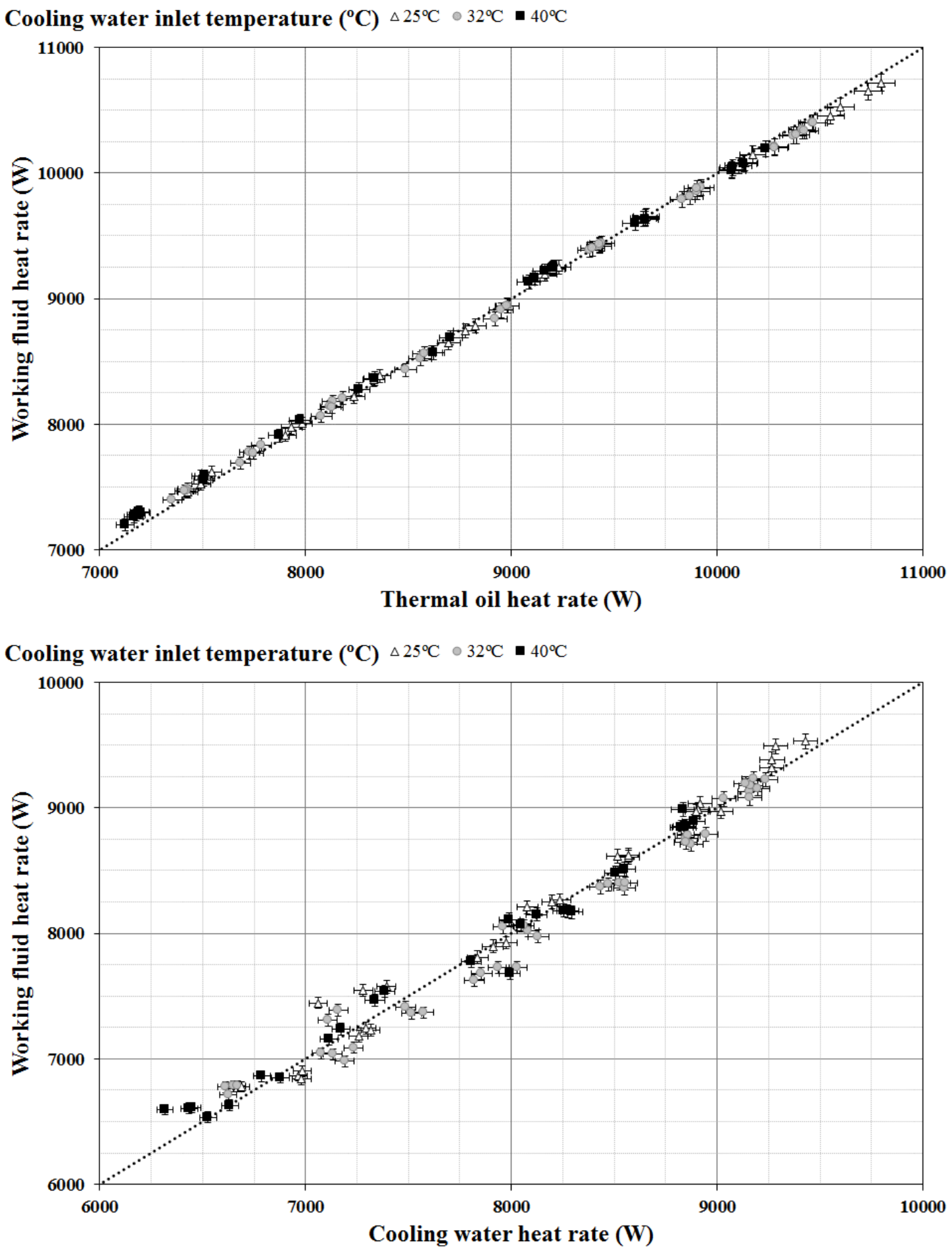

Fig. 4. Data validation comparing working fluid and secondary fluids heat transfer rates at the evaporator and condenser. 


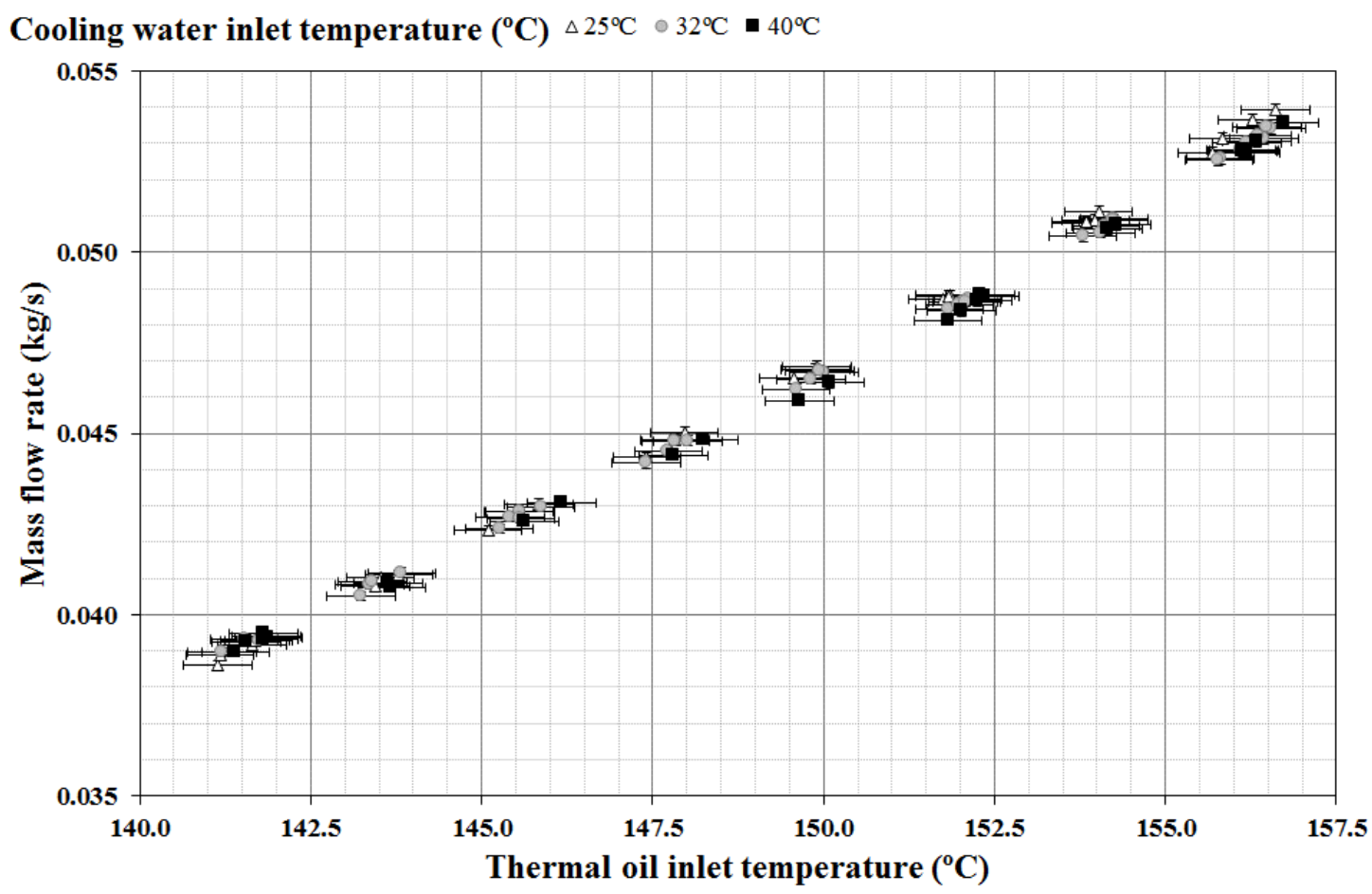

(a)

Cooling water inlet temperature $\left({ }^{\circ} \mathrm{C}\right) \triangle 25^{\circ} \mathrm{C} \circ 32^{\circ} \mathrm{C}-40^{\circ} \mathrm{C}$

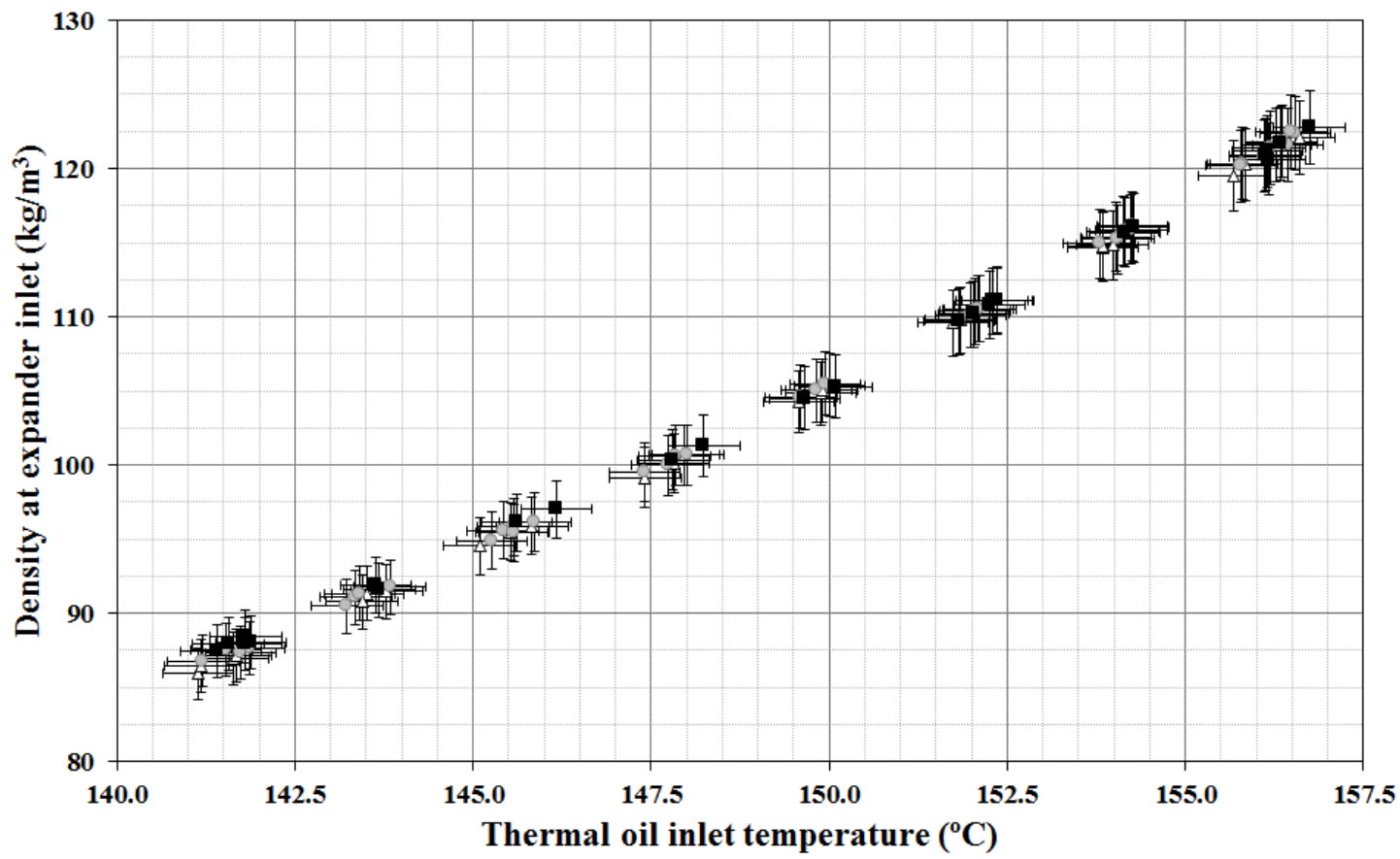

(b) 
Cooling water inlet temperature $\left({ }^{\circ} \mathrm{C}\right) \triangle 25^{\circ} \mathrm{C} \odot 32^{\circ} \mathrm{C}-40^{\circ} \mathrm{C}$

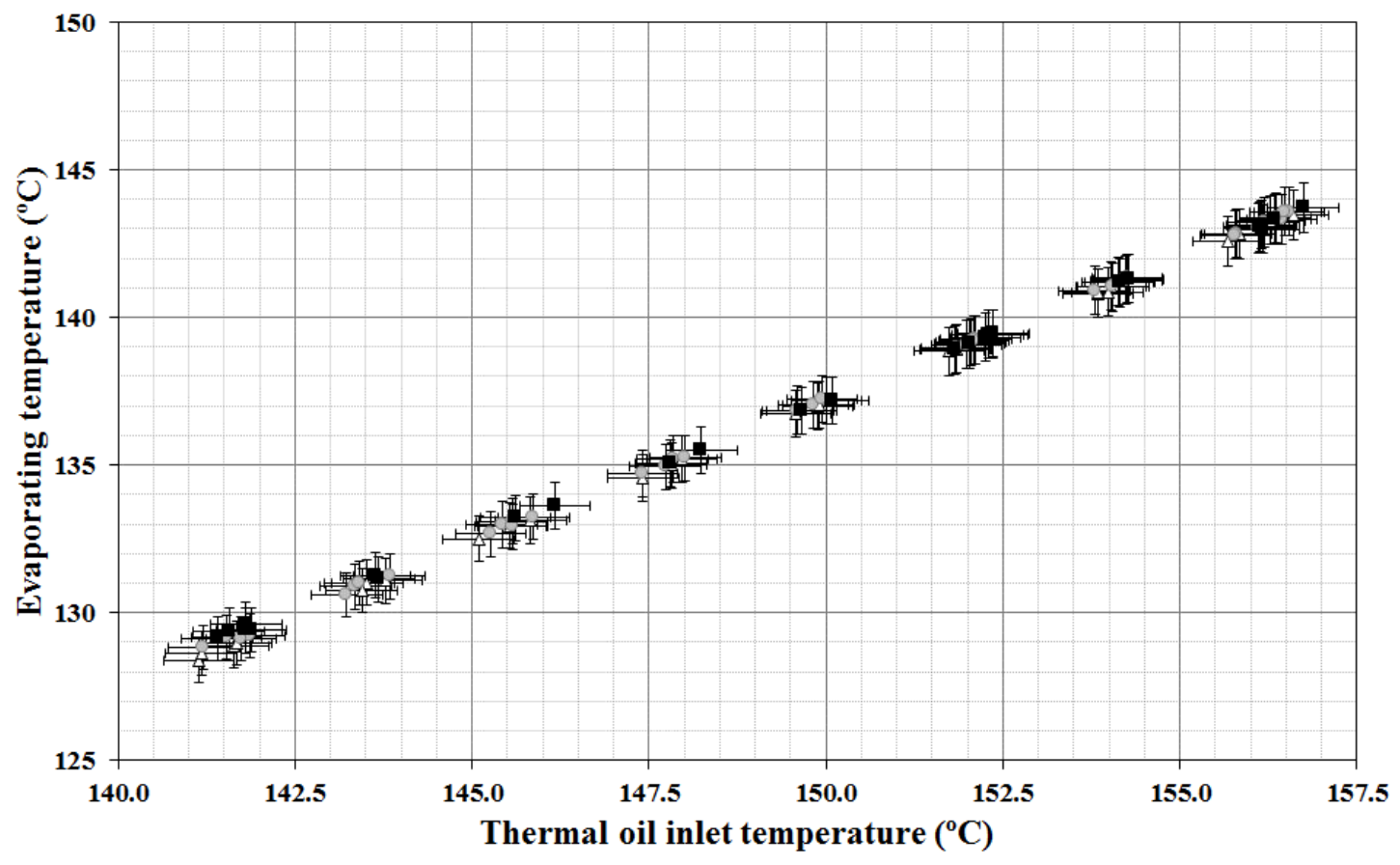

(c)

Cooling water inlet temperature $\left({ }^{\circ} \mathrm{C}\right) \Delta 25^{\circ} \mathrm{C} \circ 32^{\circ} \mathrm{C}-40^{\circ} \mathrm{C}$

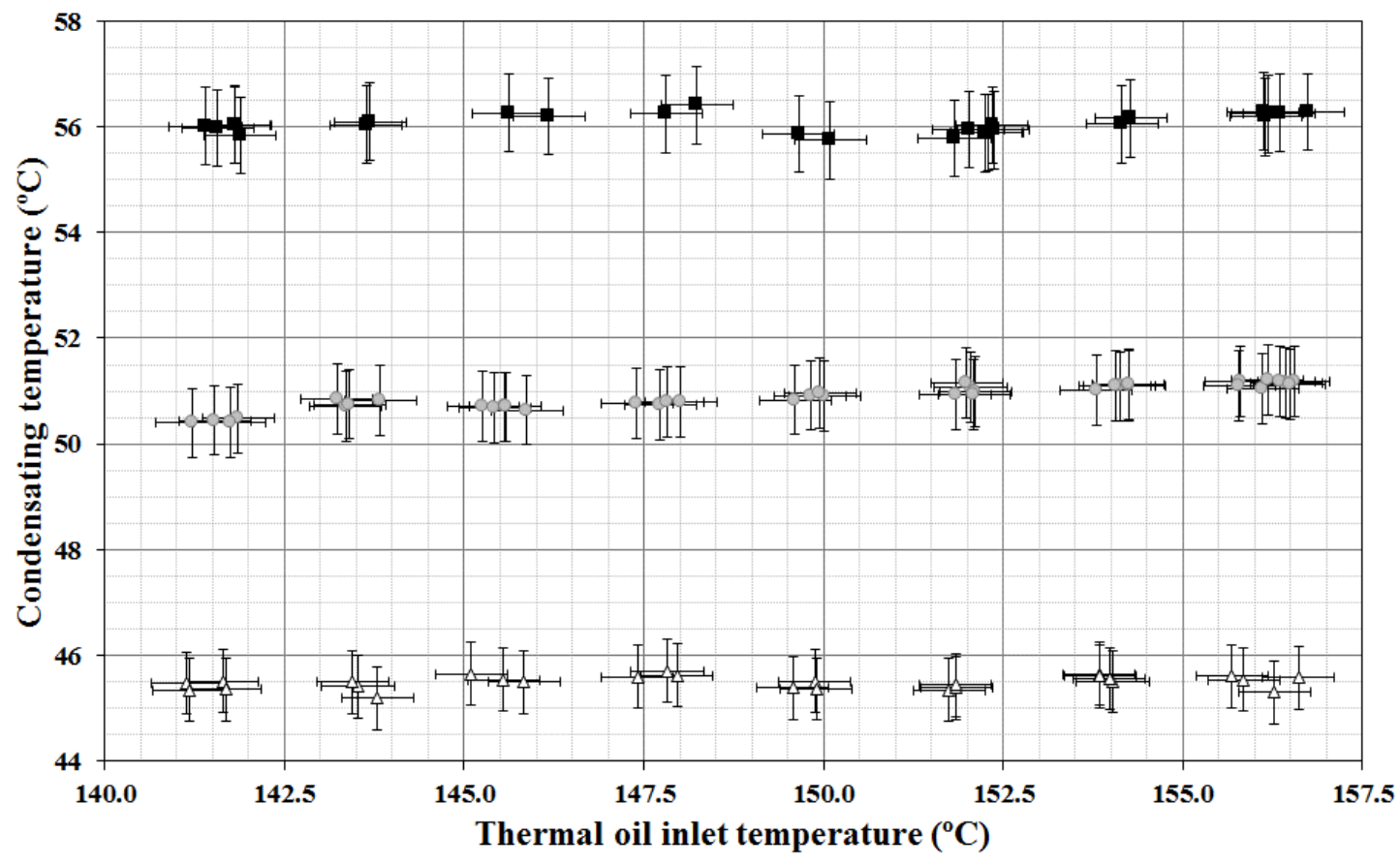

(d)

Fig. 5. (a) Mass flow rate, (b) density at expander inlet, (c) evaporating temperature and (d) condensing temperature. 


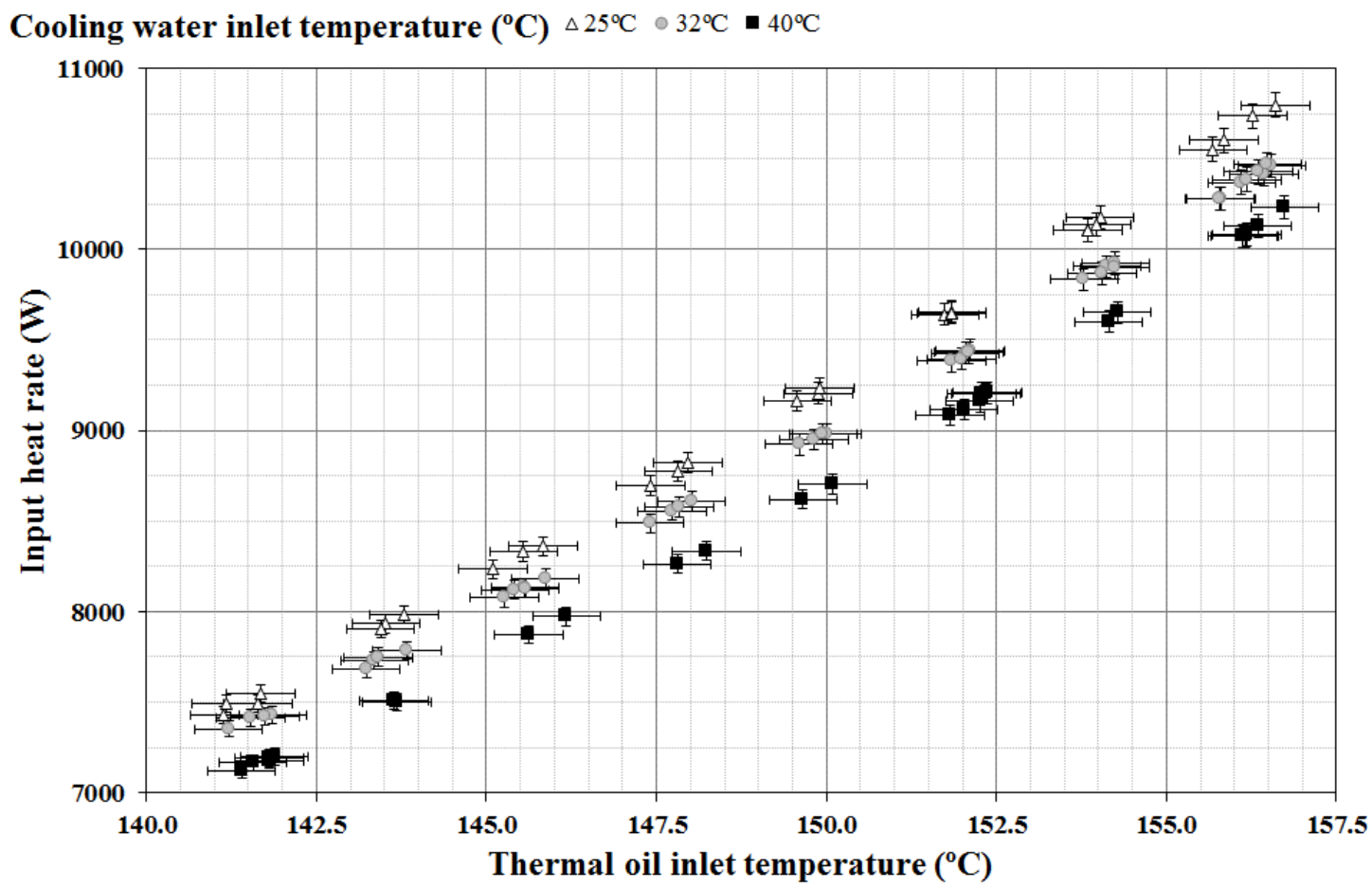

(a)

Cooling water inlet temperature $\left({ }^{\circ} \mathrm{C}\right) \triangle 25^{\circ} \mathrm{C} \circ 32^{\circ} \mathrm{C}-40^{\circ} \mathrm{C}$

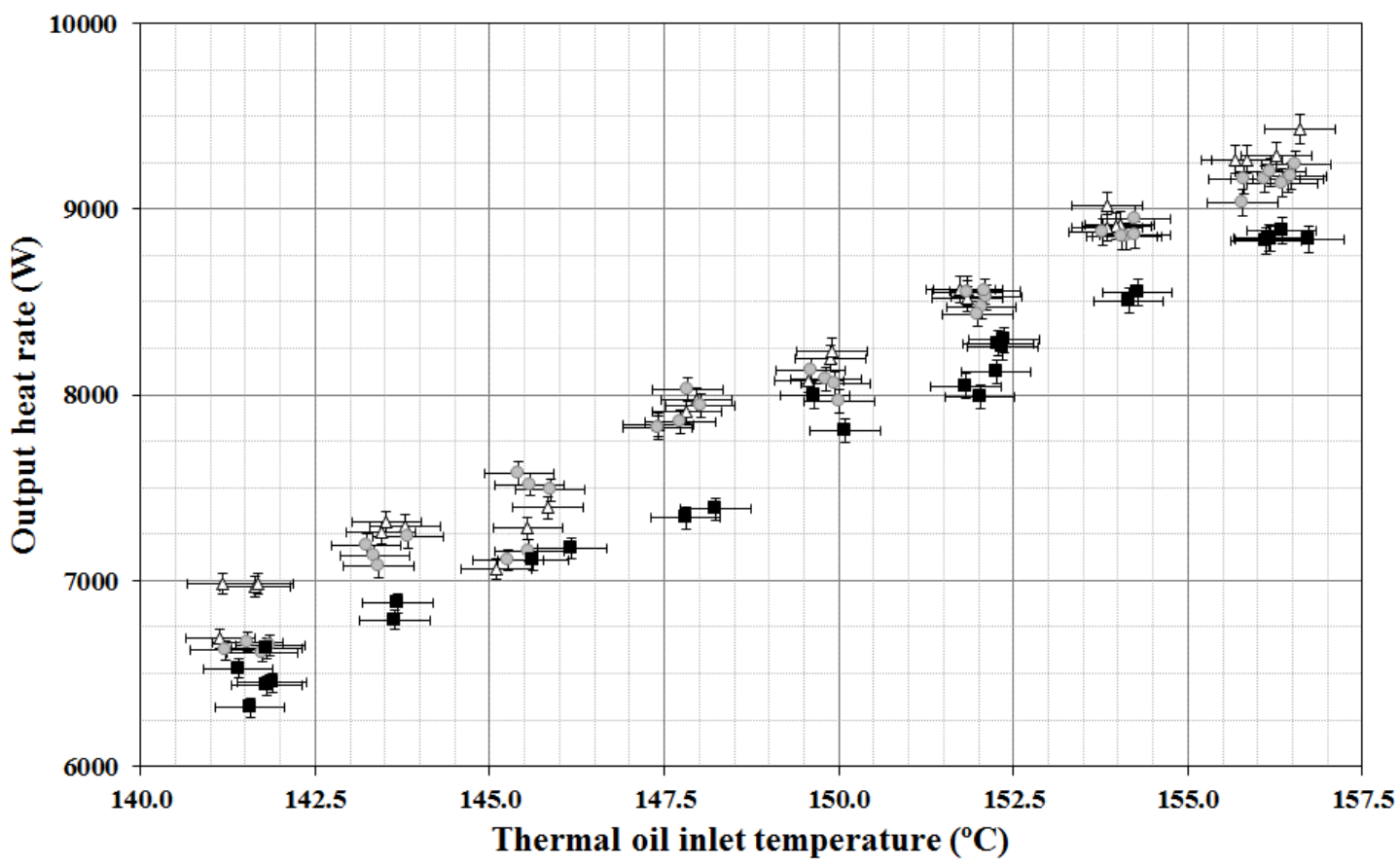

(b) 


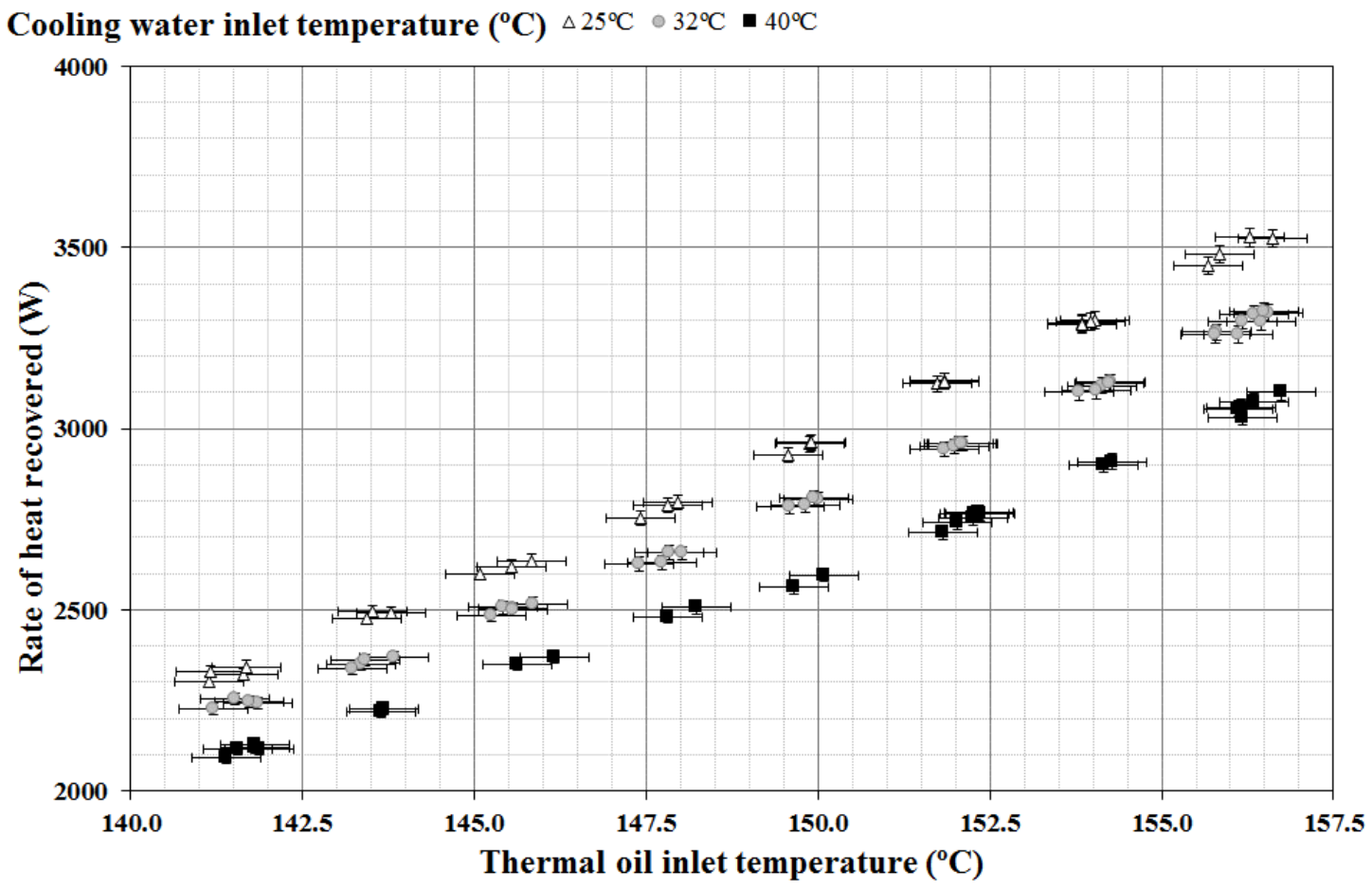

(c)

Cooling water inlet temperature $\left({ }^{\circ} \mathrm{C}\right) \triangle 25^{\circ} \mathrm{C} \cdot 32^{\circ} \mathrm{C}-40^{\circ} \mathrm{C}$

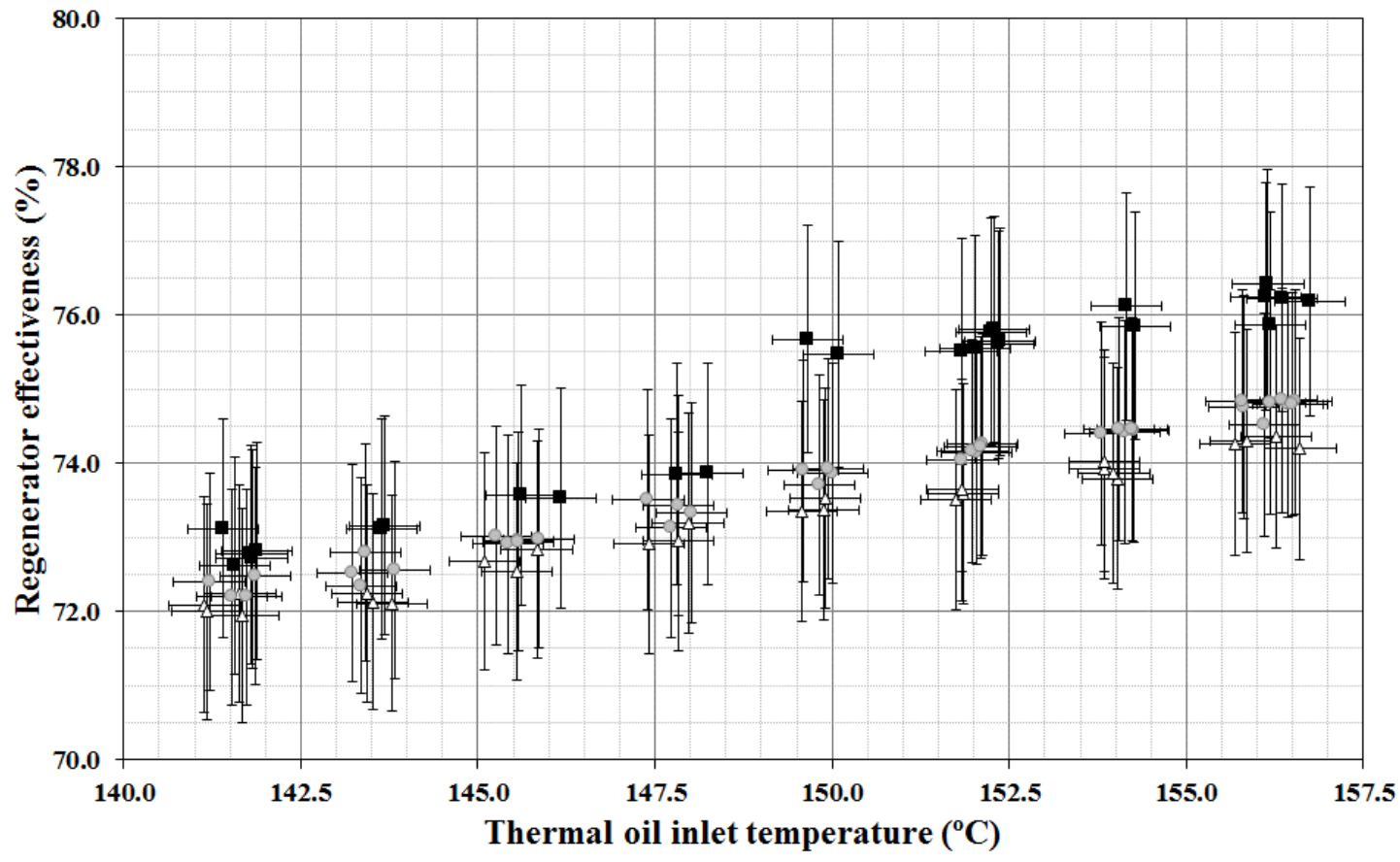

(d)

Fig. 6. (a) Input heat rate, (b) output heat rate, (c) rate of heat recovered by regenerator and $(\mathrm{d})$ regenerator effectiveness. 
Cooling water inlet temperature $\left({ }^{\circ} \mathrm{C}\right) \Delta 25^{\circ} \mathrm{C} \odot 32^{\circ} \mathrm{C}-40^{\circ} \mathrm{C}$

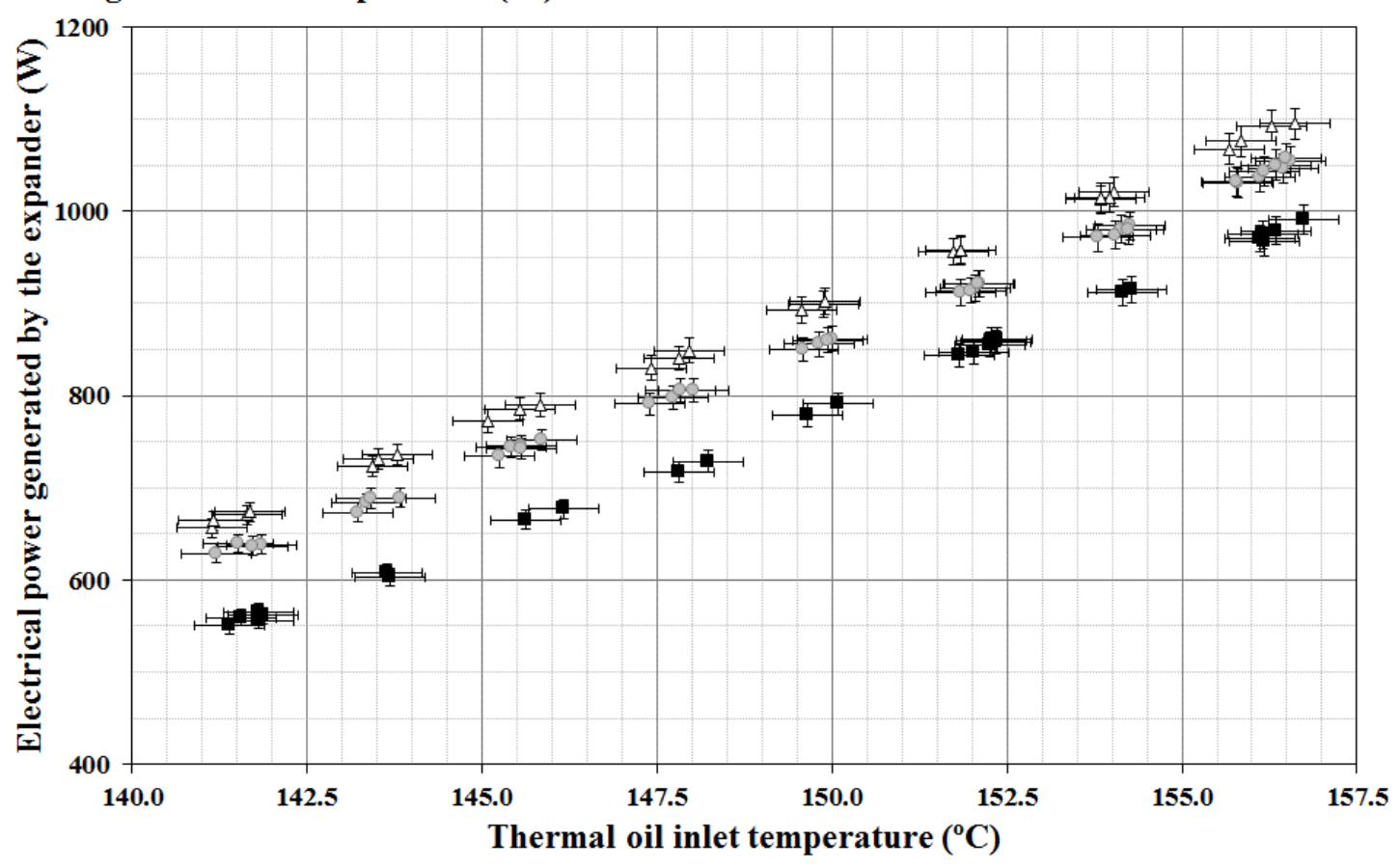

(a)

Cooling water inlet temperature $\left({ }^{\circ} \mathrm{C}\right) \Delta 25^{\circ} \mathrm{C} \odot 32^{\circ} \mathrm{C}-40^{\circ} \mathrm{C}$

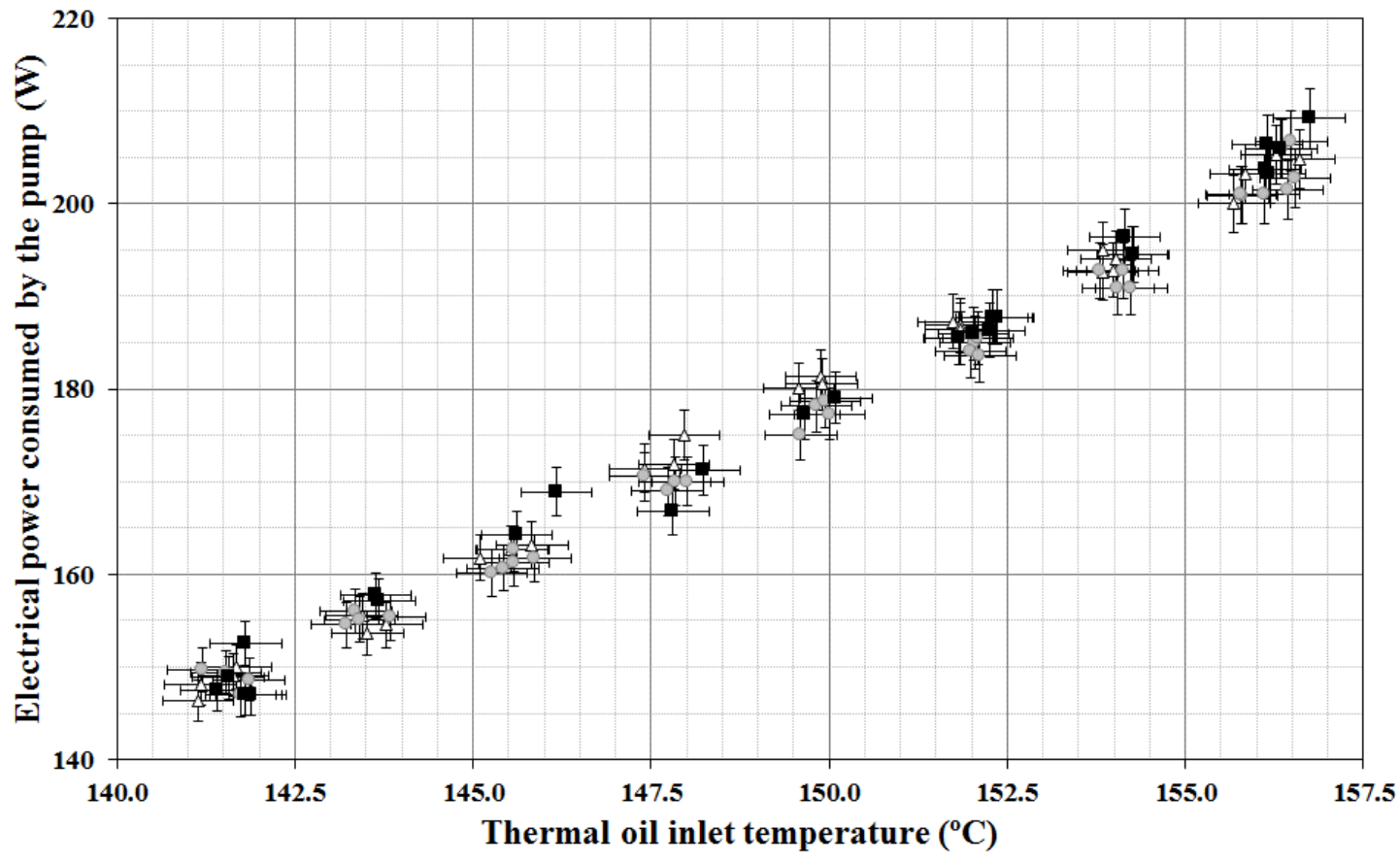

(b) 


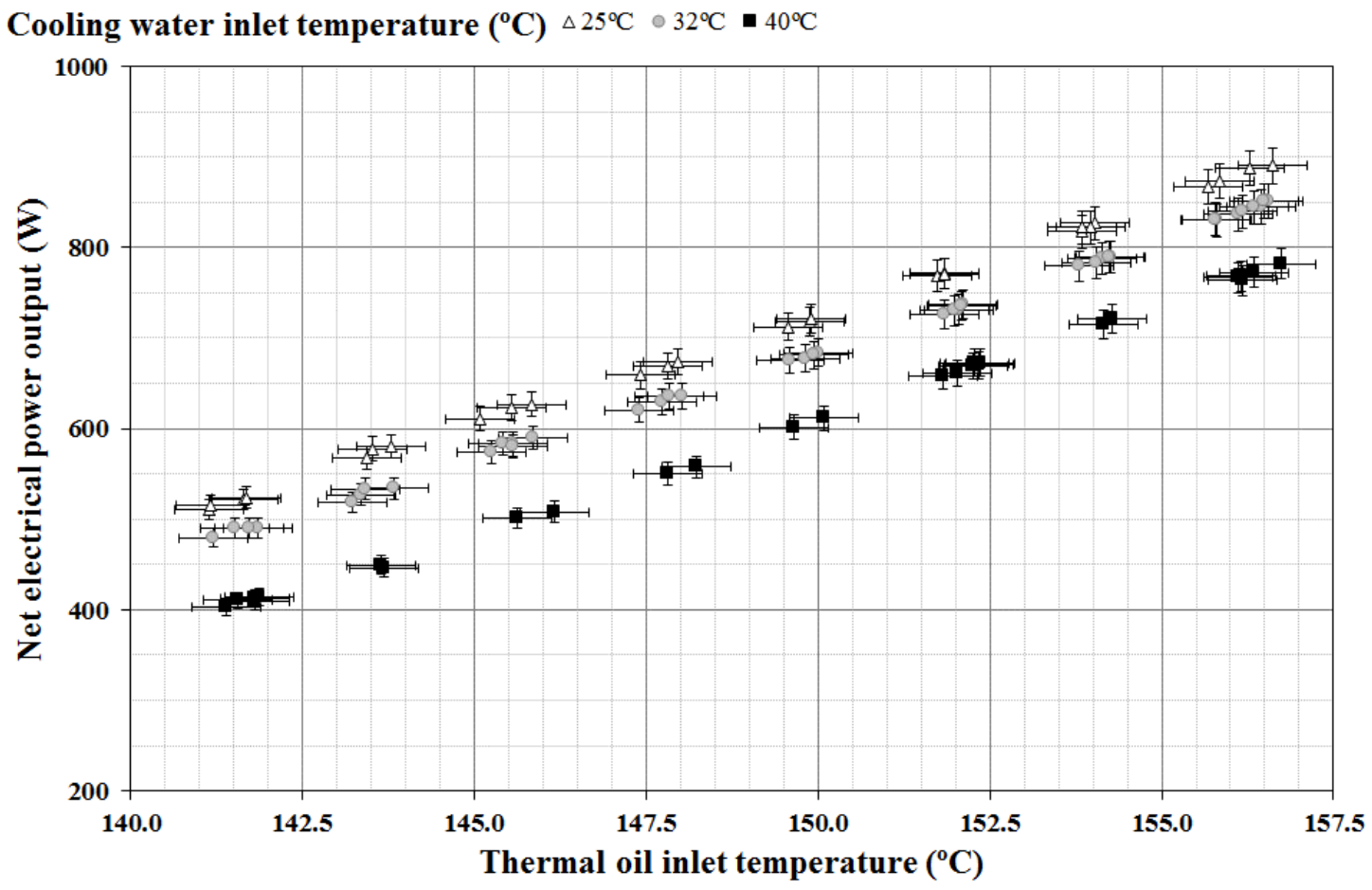

(c)

Cooling water inlet temperature $\left({ }^{\circ} \mathrm{C}\right) \triangle 25^{\circ} \mathrm{C} \bullet 32^{\circ} \mathrm{C}-40^{\circ} \mathrm{C}$

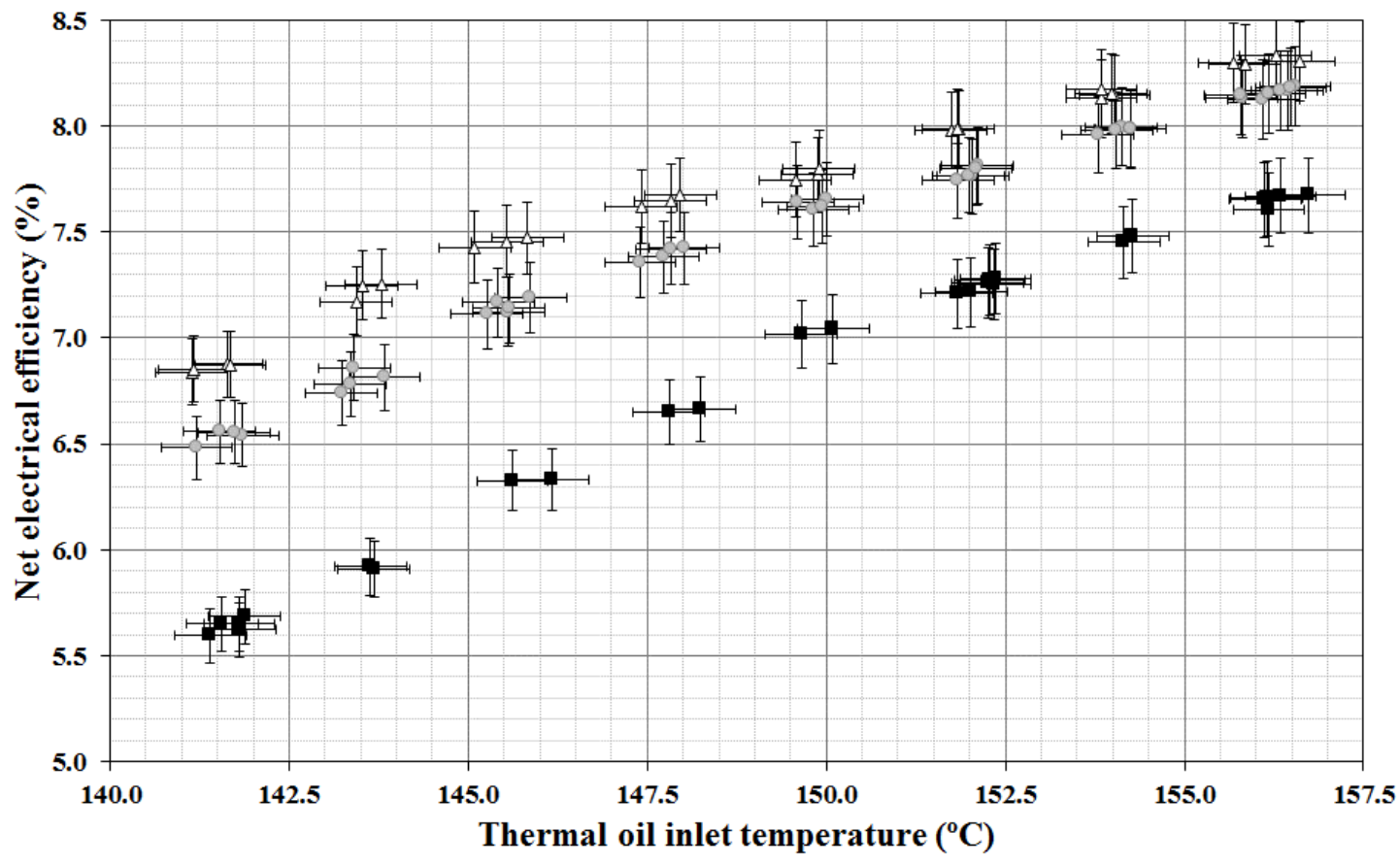

(d)

Fig. 7. (a) Electrical power generated by the expander, (b) electrical power consumed by the pump, (c) net electrical power output and (d) net electrical efficiency. 


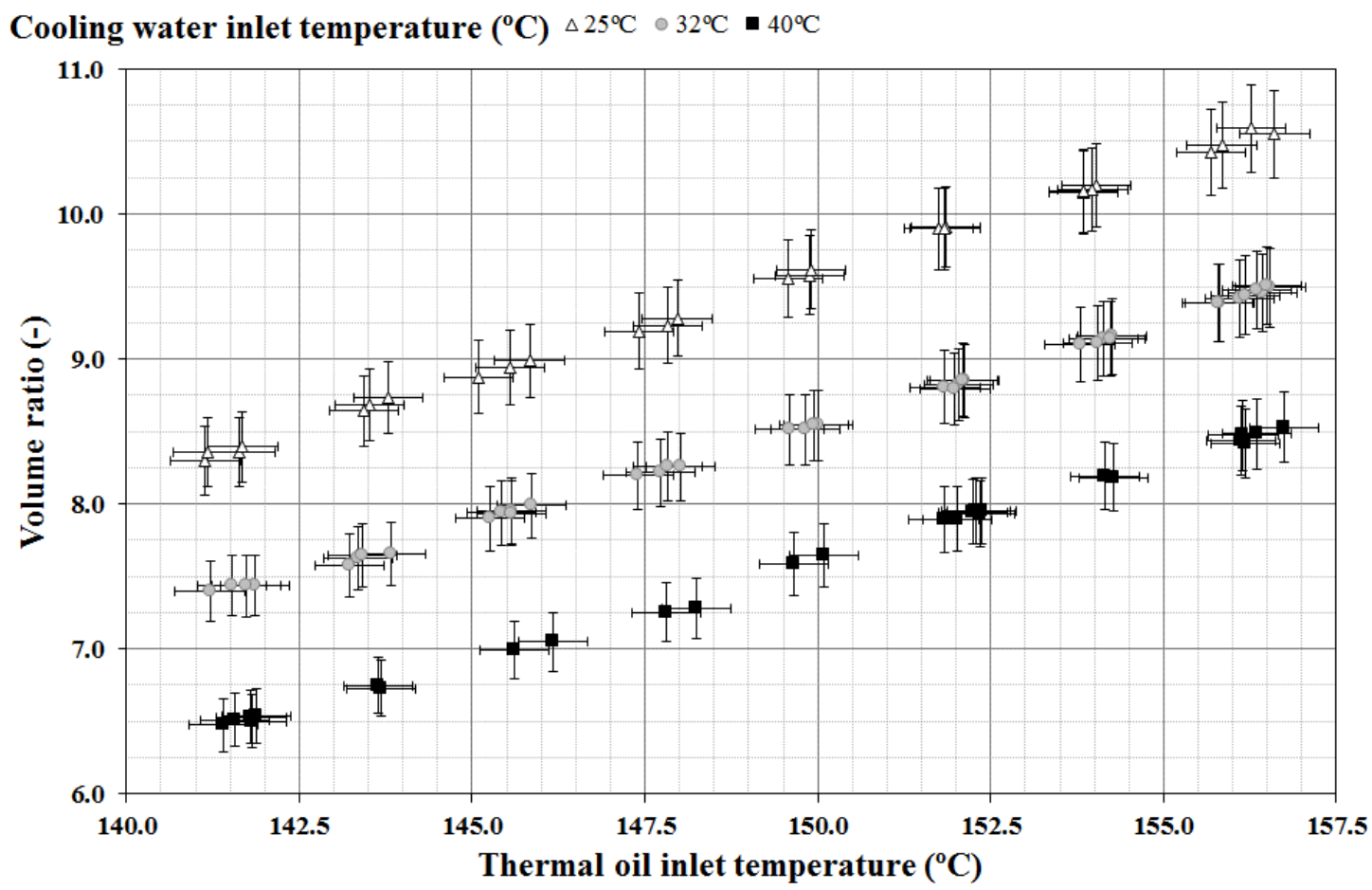

(a)

Cooling water inlet temperature $\left({ }^{\circ} \mathrm{C}\right) \triangle 25^{\circ} \mathrm{C} \circ 32^{\circ} \mathrm{C}-40^{\circ} \mathrm{C}$

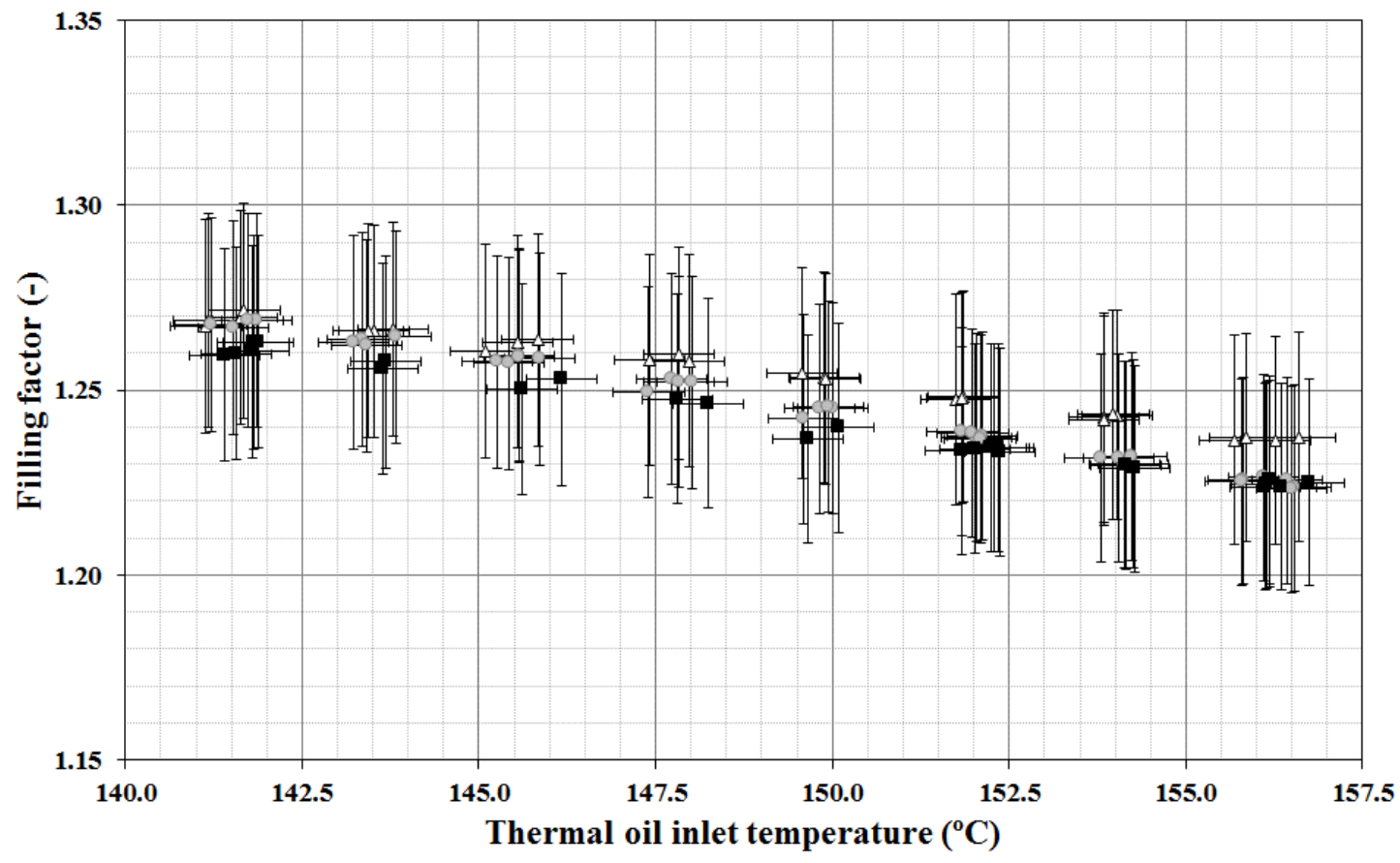

(b) 


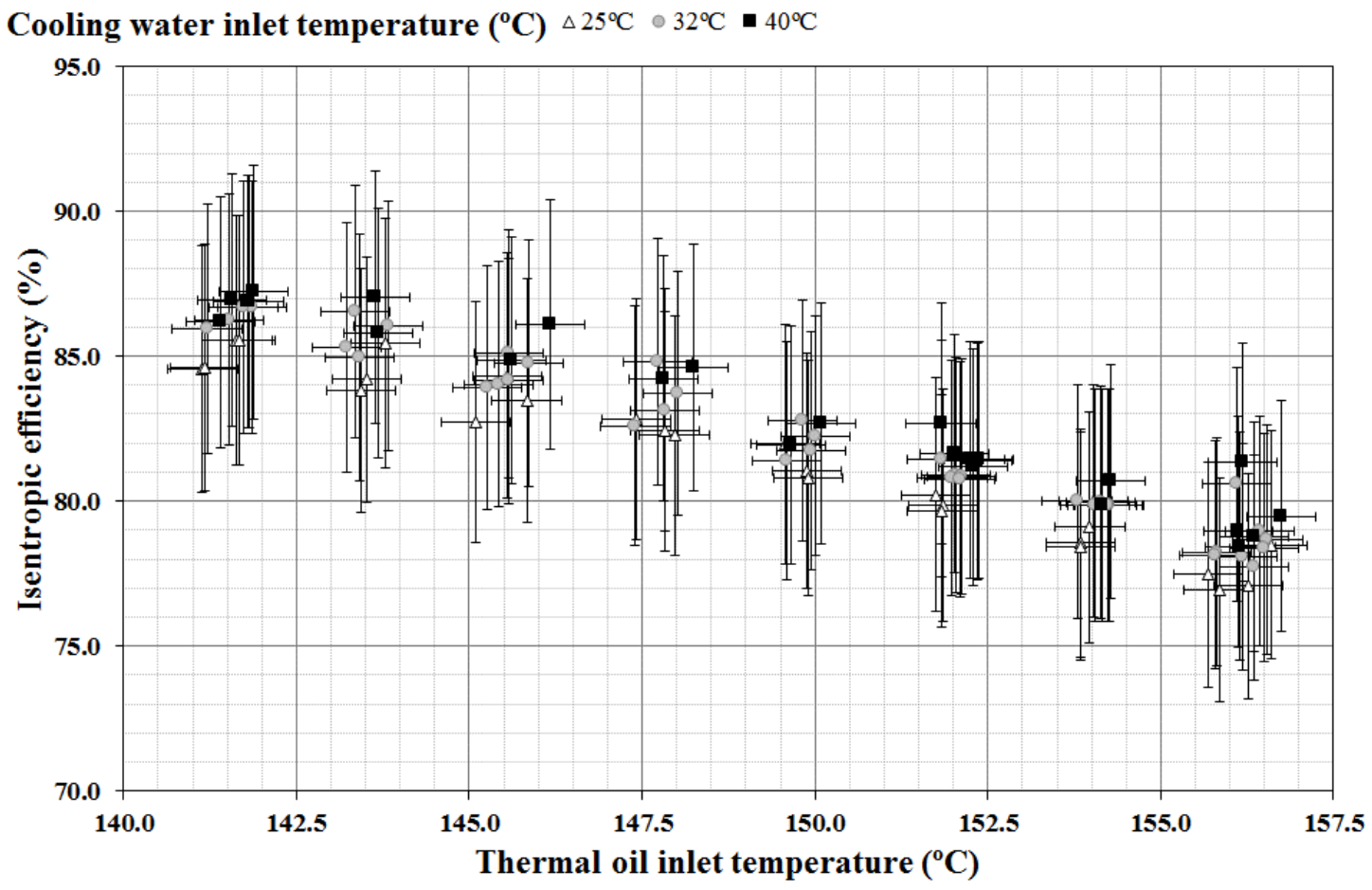

(c)

Cooling water inlet temperature $\left({ }^{\circ} \mathrm{C}\right) \triangle 25^{\circ} \mathrm{C} \circ 32^{\circ} \mathrm{C}-40^{\circ} \mathrm{C}$

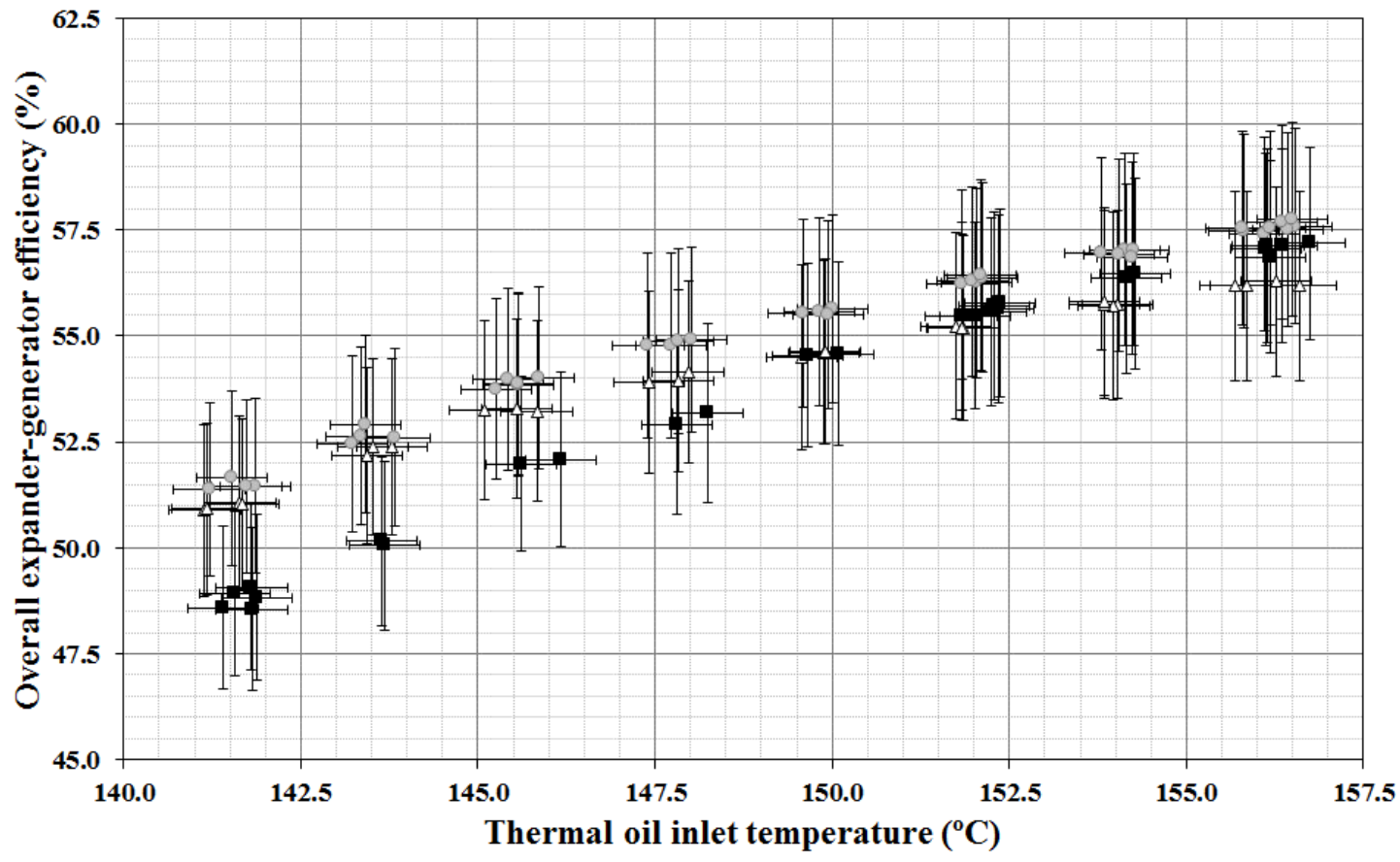

(d)

Fig. 8. (a) Volume ratio, (b) filling factor, (c) isentropic efficiency and (d) overall expander-generator efficiency. 


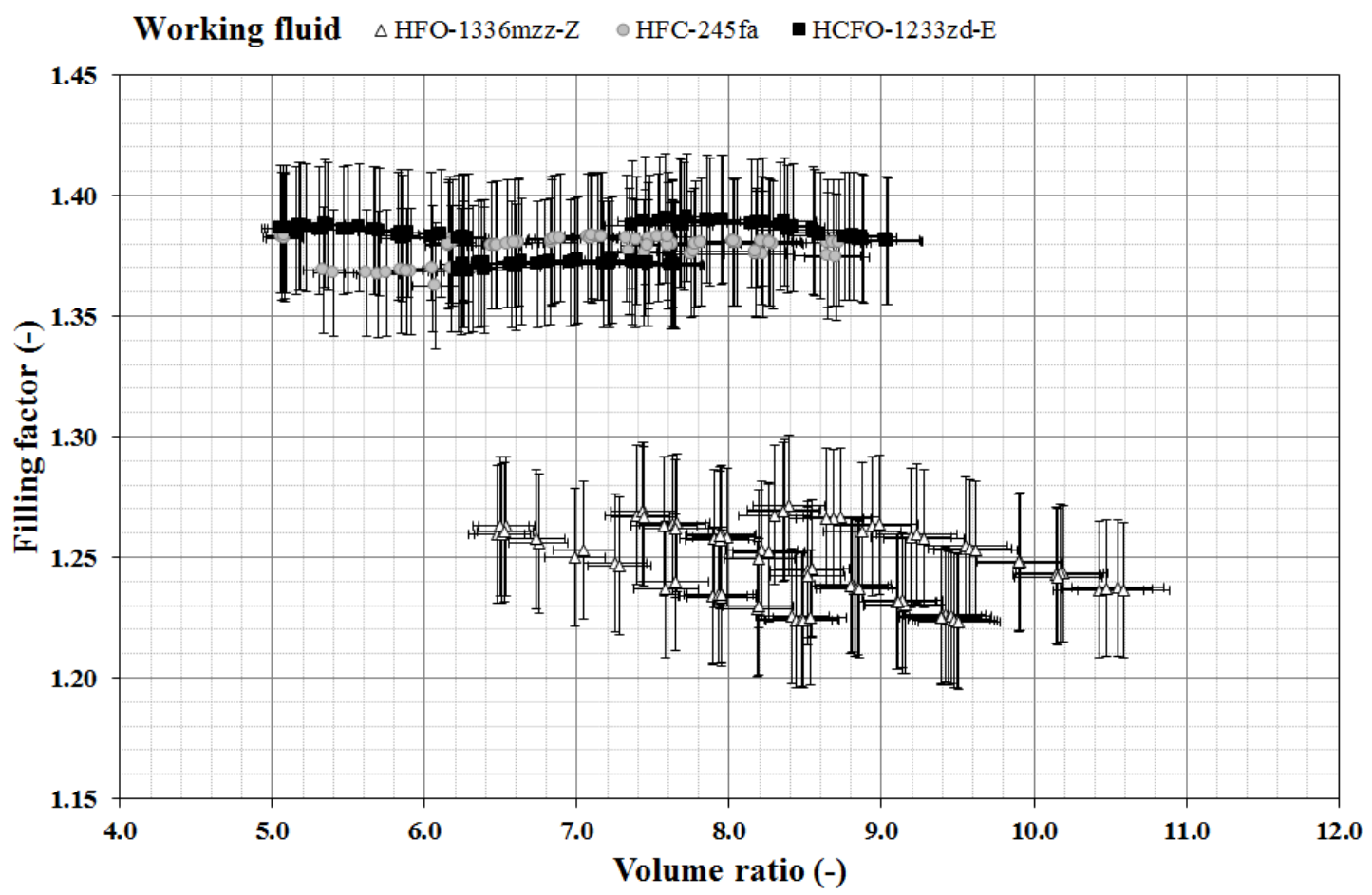

(a)

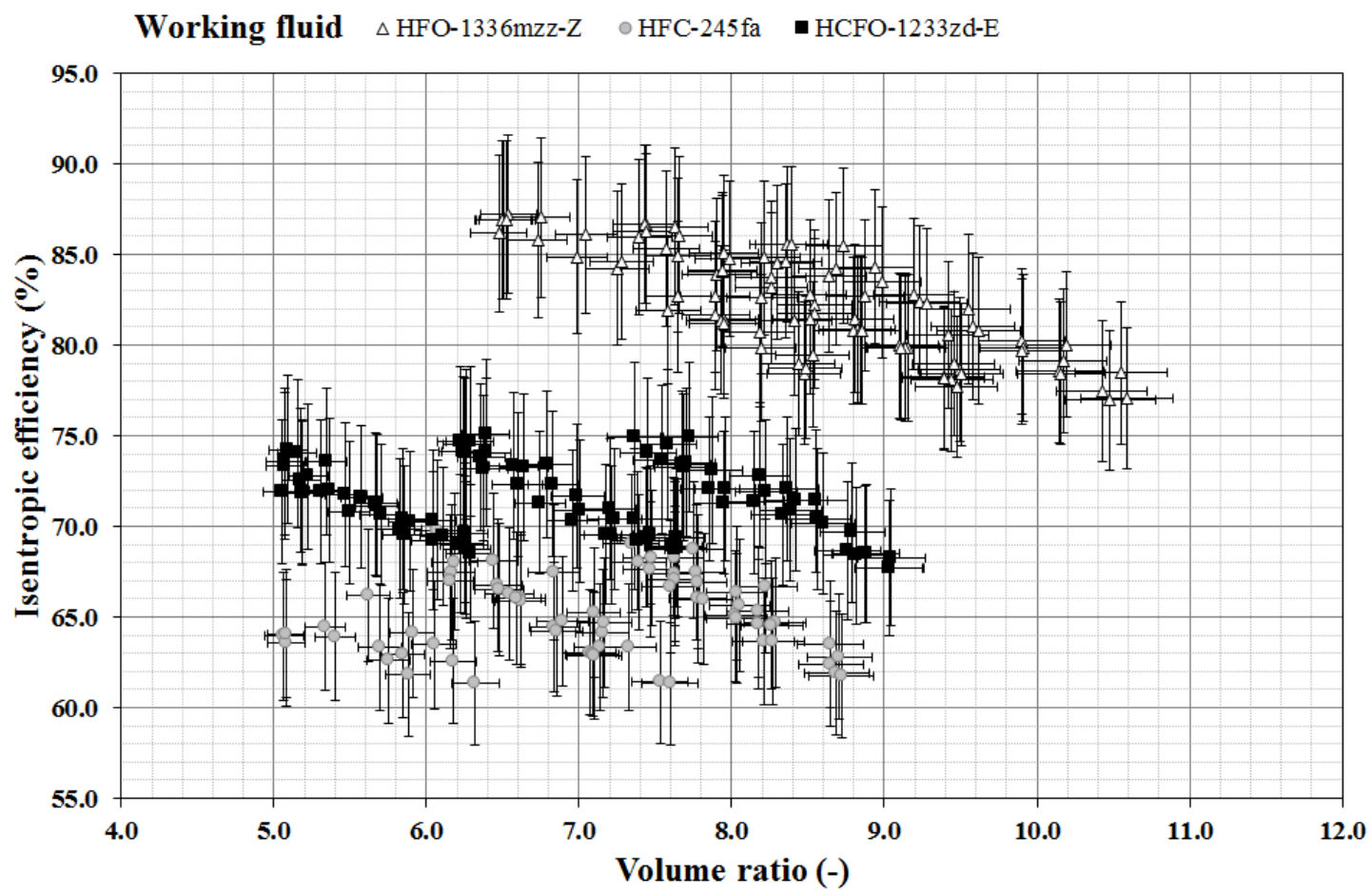

(b) 


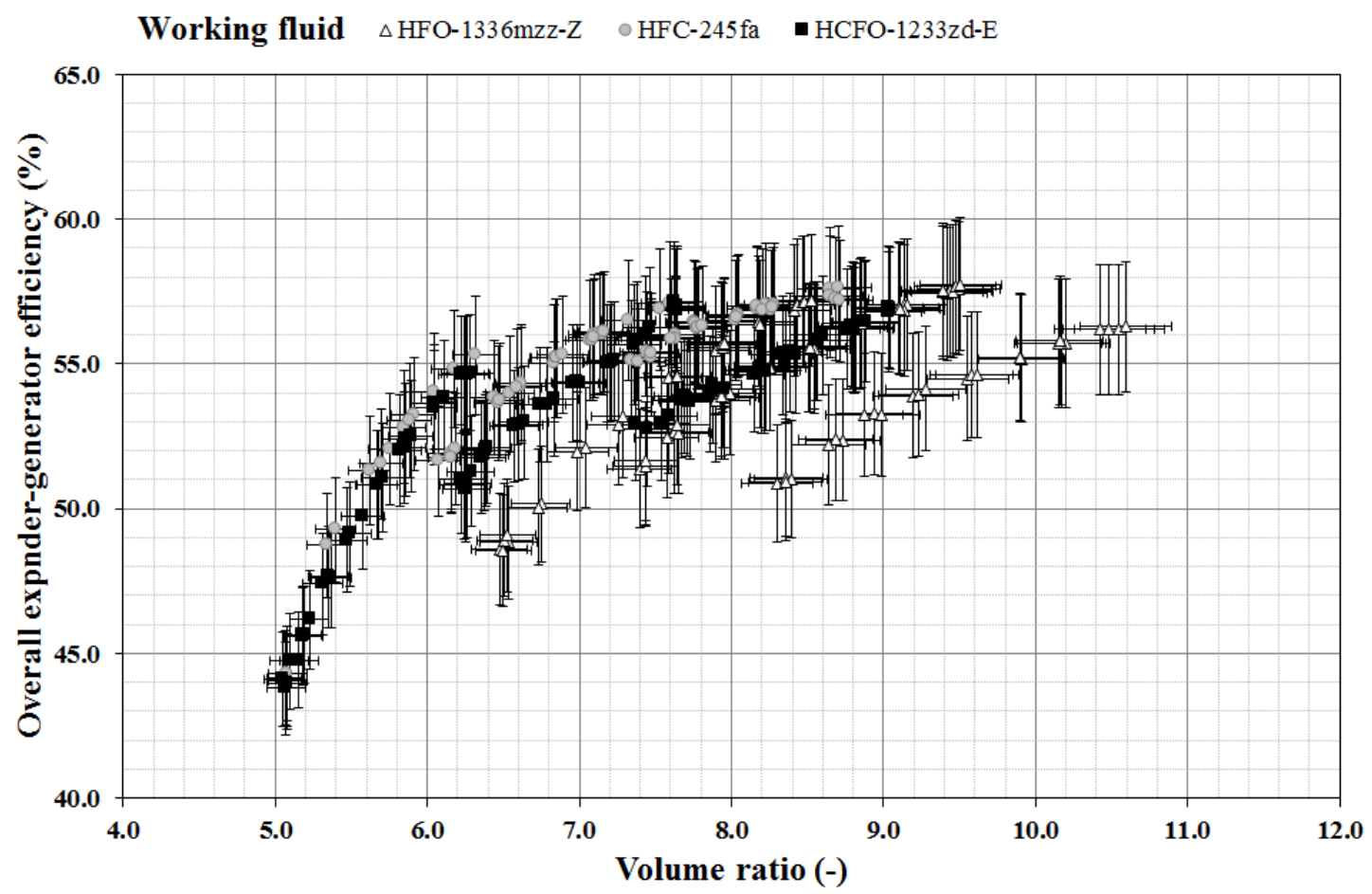

(c)

Fig. 9. Comparison for different working fluids of: (a) filling factor, (b) isentropic efficiency and (c) overall expander-generator efficiency. 


\section{FIGURE CAPTIONS}

Fig. 1. T-s diagram and vapor pressure curves for HFC-245fa and HFO-1336mzz-Z.

Fig. 2. Schematic representation of a regenerative ORC.

Fig. 3. Thermal oil and cooling water inlet temperatures obtained during steady-state tests.

Fig. 4. Data validation comparing working fluid and secondary fluids heat transfer rates at the evaporator and condenser.

Fig. 5. (a) Mass flow rate, (b) density at expander inlet, (c) evaporating temperature and (d) condensing temperature.

Fig. 6. (a) Input heat rate, (b) output heat rate, (c) rate of heat recovered by regenerator and $(\mathrm{d})$ regenerator effectiveness.

Fig. 7. (a) Electrical power generated by the expander, (b) electrical power consumed by the pump, (c) net electrical power output and (d) net electrical efficiency.

Fig. 8. (a) Volume ratio, (b) filling factor, (c) isentropic efficiency and (d) overall expander-generator efficiency.

Fig. 9. Comparison for different working fluids of: (a) filling factor, (b) isentropic efficiency and (c) overall expander-generator efficiency. 
Table 1. Thermophysical properties of HFC-245fa and HFO-1336mzz-Z.

\begin{tabular}{lcc}
\hline Parameters & HFC-245fa & HFO-1336mzz-Z \\
\hline $\mathrm{T}_{\mathrm{cr}}\left({ }^{\circ} \mathrm{C}\right)$ & 154.01 & 171.3 \\
$\mathrm{P}_{\mathrm{c}}(\mathrm{MPa})$ & 3.65 & 2.9 \\
Mol. w. $(\mathrm{kg} / \mathrm{kmol})$ & 134 & 164 \\
Slope & Dry & Dry \\
OEL $(\mathrm{ppm})$ & 300 & 500 \\
Flammability & Non flammable & Non flammable \\
ASHRAE Standard 34 Safety Class & $\mathrm{B} 1$ & $\mathrm{~A} 1$ \\
$\mathrm{ALT}(\mathrm{yr})$ & 7.6 & 0.060274 \\
ODP & 0 & 0 \\
$\mathrm{GWP}$ & 858 & 2 \\
Boiling point $\left({ }^{\circ} \mathrm{C}\right)$ & 14.81 & 33.4 \\
Latent heat at boiling point $(\mathrm{kJ} / \mathrm{kg})$ & 196.23 & 165.67 \\
Evaporating pressure at $125^{\circ} \mathrm{C}(\mathrm{MPa})$ & 2.21 & 1.28 \\
Condensing pressure at $25^{\circ} \mathrm{C}(\mathrm{MPa})$ & 0.16 & 0.08 \\
Vapour density at $25^{\circ} \mathrm{C}\left(\mathrm{kg} / \mathrm{m}^{3}\right)$ & 9.13 & 5.38 \\
Liquid density at $25^{\circ} \mathrm{C}\left(\mathrm{kg} / \mathrm{m}^{3}\right)$ & 1333.5 & 1359.5 \\
Vapour specific heat at $25^{\circ} \mathrm{C}\left(\mathrm{kJ} / \mathrm{kg} \cdot{ }^{\circ} \mathrm{C}\right)$ & 0.96 & 0.87 \\
Liquid specific heat at $25^{\circ} \mathrm{C}\left(\mathrm{kJ} / \mathrm{kg} \cdot{ }^{\circ} \mathrm{C}\right)$ & 1.33 & 1.21 \\
\hline
\end{tabular}


Table 2. Commercial ORC module features.

\begin{tabular}{ll}
\hline Alternator rated power $(\mathrm{kW})$ & 1.5 \\
ORC configuration & Regenerative \\
Working fluid & HFO-1336mzz-Z \\
Expander technology & Volumetric (scroll) \\
Heat exchangers type & Brazed plate \\
Maximum thermal oil inlet temperature $\left({ }^{\circ} \mathrm{C}\right)$ & 160 \\
Maximum cooling water inlet temperature $\left({ }^{\circ} \mathrm{C}\right)$ & 45 \\
\hline
\end{tabular}


Table 3. Measured parameters, measuring instruments and measurement uncertainty.

\begin{tabular}{lll}
\hline Measured parameter & Sensor & Uncertainty \\
\hline Temperatures & K-type thermocouples & $\pm 0.5^{\circ} \mathrm{C}$ \\
Pressures & Piezoelectric pressure transducers & $\pm 0.5 \mathrm{kPa}$ \\
Working fluid mass flow rate & Coriolis mass flow meter & $\pm 0.3 \%$ \\
$\begin{array}{l}\text { Electrical power } \\
\text { Thermal oil volumetric flow rate }\end{array}$ & Digital wattmeter & $\pm 1.55 \%$ \\
$\begin{array}{l}\text { Cooling water volumetric flow } \\
\text { rate }\end{array}$ & Eortex flow meter & $\pm 0.028 \mathrm{~m}^{3} / \mathrm{h}$ \\
\end{tabular}


Table 4. Uncertainties for calculated parameters.

\begin{tabular}{ll}
\hline Calculated parameter & Uncertainty \\
\hline$\rho_{\text {exp }, i}$ & $\pm 2.02 \%$ \\
$T_{\text {evap }}$ & $\pm 0.58 \%$ \\
$T_{\text {cond }}$ & $\pm 1.30 \%$ \\
$\dot{Q}_{i}$ & $\pm 0.63 \%$ \\
$\dot{Q}_{o}$ & $\pm 0.80 \%$ \\
$\dot{Q}_{\text {reg }}$ & $\pm 0.70 \%$ \\
$\varepsilon_{\text {reg }}$ & $\pm 2.02 \%$ \\
$\dot{W}_{n}$ & $\pm 2.20 \%$ \\
$\eta_{n}$ & $\pm 2.28 \%$ \\
$r_{v}$ & $\pm 2.84 \%$ \\
$\varphi$ & $\pm 2.28 \%$ \\
$\varepsilon_{i s}$ & $\pm 5.02 \%$ \\
$\varepsilon_{o v}$ & $\pm 3.98 \%$ \\
\hline
\end{tabular}


Table 5. Range of operating conditions in the experimental steady-state tests.

\begin{tabular}{ll}
\hline Parameter & Range \\
\hline$T_{o i l, i}\left({ }^{\circ} \mathrm{C}\right)$ & $141.14-156.74$ \\
$T_{o i l, o}\left({ }^{\circ} \mathrm{C}\right)$ & $129.93-141.65$ \\
$\dot{V}_{o i l}\left(\mathrm{~m}^{3} / \mathrm{h}\right)$ & $1.28-1.30$ \\
$T_{w, i}\left({ }^{\circ} \mathrm{C}\right)$ & $25.00-40.47$ \\
$T_{w, o}\left({ }^{\circ} \mathrm{C}\right)$ & $27.12-42.60$ \\
$\dot{V}_{w}\left(\mathrm{~m}^{3} / \mathrm{h}\right)$ & $3.39-3.44$ \\
$\mathrm{SH}\left({ }^{\circ} \mathrm{C}\right)$ & $10.18-10.54$ \\
\hline
\end{tabular}

